\title{
Fragility, Perseverance, and Survival in State-Run Philippine Archives
}

\section{Bliss Cua Lim}

This article considers the consequences of the 2004 dissolution of the Philippine Information Agency's Motion Picture Division (PIA-MPD) on three key collections entrusted to it: films from the National Media Production Center; from the Movie and Television Review and Classification Board (themselves remnants of the previous archival collapse of the Film Archives of the Philippines in 1986); and lastly, a number of films produced by LVN Pictures, a studio founded in 1938. Using approaches from cultural policy, archival theory, feminist epistemology, and postcolonial historiography, the essay draws on an array of sources-archival films, legislative records, PIA documents, oral history interviews, and personal papers from members of the Society of Filipino Archivists for Film and the South East Asia Pacific Audio Visual Archives Association. The aftermath of the PIA-MPD's abolition underscores the drawbacks of a narrowly profit-driven perspective on state film archiving that devalued analog cinema in relation to digital media while also ignoring the unique demands of audiovisual (AV) archiving by conflating it with paper-based librarianship. This study affirms the Filipino AV archive advocacy's repeated calls for legislation to safeguard the institutional continuity and autonomy of Philippine film archives from the vagaries of political whim. Reflecting on the archivist-activists who endured the decline of various state-run film collections, the article concludes by conceptualizing archival survival as not only involving the material preservation of analog or digital AV carriers but as also entailing exhaustion and persistence on the part of archivists who persevere in institutional conditions they work to change.

Keywords: Philippine film archives; Philippine Information Agency's Motion Picture Division (PIA-MPD), National Media Production Center (NMPC), Movie and Television Review and Classification Board (MTRCB), LVN Pictures, archival theory, feminist epistemology, enduring and archival survival

The contours of Philippine cinema's archival crises are alarming: of over 350 films produced before the outbreak of World War II, only five complete Filipino films from the American colonial period survive in some form (Junio, 2003, pp.7-8; Del Mundo, 1998, pp. 7-8; Deocampo, 2004) ${ }^{1}$. Although a comprehensive 2003 inventory of Philippine audiovisual collections identified one extant nitrate film, Vicente Salumbides and Manuel Conde's 1941 Ibong Adarna [Adarna Bird], I recently learned that Ibong Adarna's nitrate dupe negative was disposed of after the 2005 restoration of the film (Galino, 2018). ${ }^{2}$ That no nitrate elements of a domestically-produced Filipino film are known to survive is an exceptionally bleak statistic-even by comparison to the dismal survival rates of nitrate cinema worldwideand functions as a kind of shorthand for the archival fragility of Philippine cinema. $^{3}$

Decisions to preserve, neglect, or imperil remnants of the past are never neutral; power is at the crux of the social existence of archives. Archiving is an inherently political activity since it involves "an assertion of values 
and hence of a viewpoint" on how much of the past will be allowed to survive. Contemporary archival theory calls for analysis of the multifaceted deployment of archival power, which includes, but is not limited to, the "power to make records of certain events and ideas and not of others..., power to preserve the record, power to mediate the record, power of access...over collective memory and national identity" and not least, "power over information and power of information institutions" (Scwartz and Cook, 2002, pp 5, 9). The political dimension of archiving demands high ethical standards for those charged with the care of cultural memory, given that much of archival work is unmonitored and unvalidated. Since media preservation is always a process of straining against processes of deterioration that will inevitably take hold unless someone intervenes, "the survival of the past is constantly at the mercy of the present" (Edmondson, 2016, pp. 10, 74) and, in the Philippines, to the economic, political, and technological conditions that over-determine audiovisual archiving by state and non-governmental entities.

The dwindling number of surviving Filipino films has everything to do with the historically short-lived nature of the country's government-funded audiovisual (AV) archives; my focus here is on film. ${ }^{4}$ The foremost example of the ephemerality of state film archiving initiatives is the first Film Archives, which lasted less than five years. Established by the Marcos dictatorship in 1981 (Marcos, 1981), ${ }^{5}$ it shuttered shortly after the regime's ouster by the 1986 People Power Revolt, which ushered in the presidency of Corazon "Cory" Aquino. In 2011, after 25 years of state neglect had irreversibly damaged the majority of the Philippines' film holdings, the present-day National Film Archives of the Philippines (NFAP) was revived. However, it was deprioritized by the Film Development Council of the Philippines (FDCP) upon President Rodrigo Duterte's election in $2016 .{ }^{6}$ Lacking a permanent repository for its collection and a firm legislative mandate, the long-term prospects of the reinvented NFAP, regardless of regime change and short-term presidential appointees to key film posts, are not assured (Lim, 2013b). Historically, permanent sustainability is both the most urgent and the most enduring problem for state-funded Filipino film archives. This is why the Sisyphean story of the NFAP has broad parallels with the tragic demise of other key government media collections. ${ }^{7}$

The ensuing discussion focuses on the dissolution of the Philippine Information Agency's Motion Picture Division (PIA-MPD) and the posthumous fate of its film collection. I say "posthumous" because the MPD's internationally prominent Film Laboratory and Film Library were shut down in 2004 by order of Renato S. Velasco, the PIA Director-General appointed by President Gloria Macapagal-Arroyo, on the grounds that government 
cost-cutting and the shift to digital media made the unit an ineffective use of state resources. Concurrent with the closure of the MPD was the creation of a new Management Information Systems Division (MISD), to which several former MPD personnel were re-deployed (Velasco, 2004a, 2004b, 2004c, 2004d). ${ }^{8}$ The closure of the MPD amounts to a momentous yet little-known instance of heritage destruction conducted in the absence of a documented archival policy. ${ }^{9}$ The aim of the ensuing analysis is not to fault individual decisions but to underscore the historical significance of the Philippines' audiovisual past and to learn from the unintended consequences of the dissolution of the PIA-MPD.

On my first research visits to the PIA Film Vault in August and September 2014-a decade after the MPD was dissolved-I encountered an extensive but derelict collection. ${ }^{10}$ In the absence of rigorous temperature and humidity controls (the Film Vault was not even air-conditioned), several film cans dripped black ooze (Figures 1-3). The scent of vinegar, an index of deteriorating acetate film stock, hung heavy in the air. ${ }^{11}$

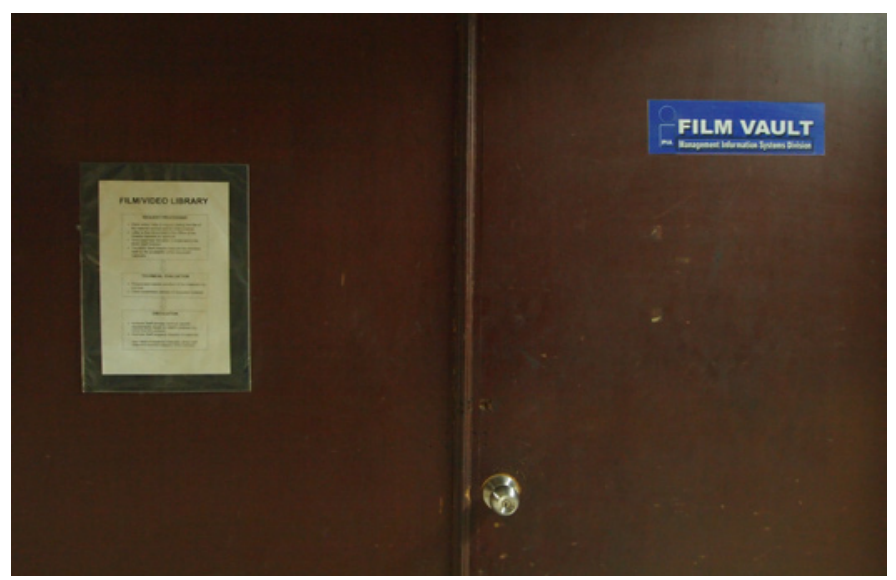

Figs. 1-3. Photos by author, August and September 2014.

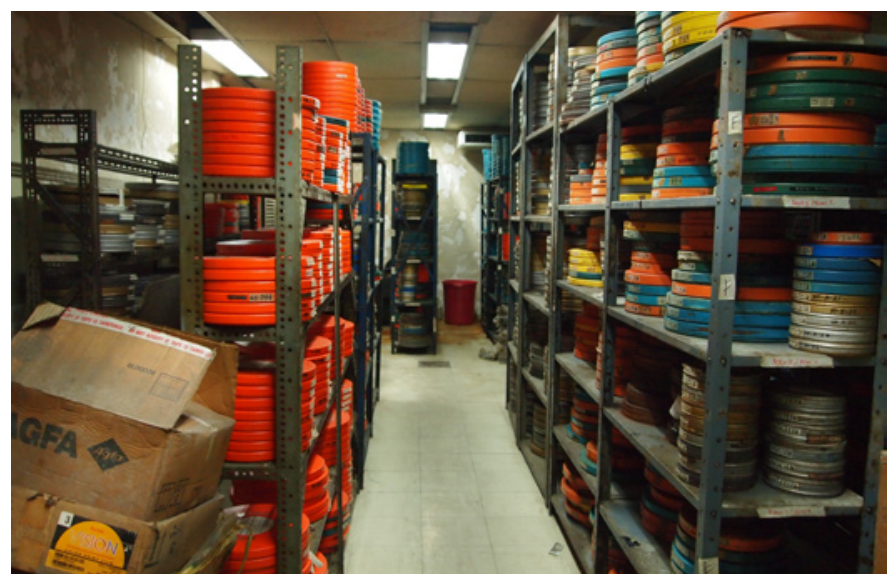

Fig. 2. Inside the PIA Film Vault. 


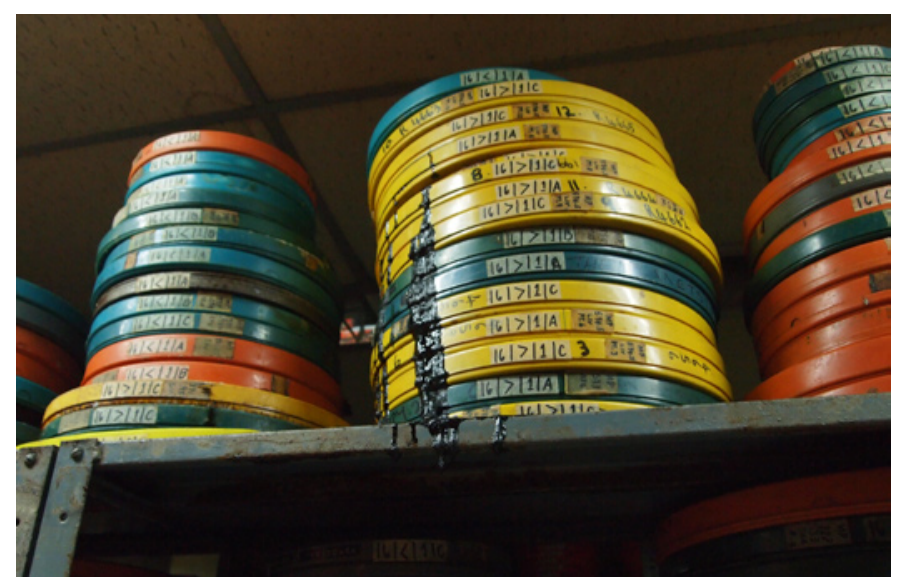

Fig. 3. Black ooze can be seen dripping from film canisters stored at the PIA Film Vault.

To clarify, despite the PIA-MPD's significant archival film initiatives, the agency was never an official state film archive; instead the PIA's mandate centers on the dissemination of "development-oriented public Information" through media and information/communications technology (Aquino, 1986). Key figures at the MPD were active both in domestic and regional AV archive organizations: the Society of Filipino Archivists for Film (SOFIA), which functioned as the lead nongovernmental "coordinating body" in media preservation and restoration projects (Capul, 1997), and the Southeast Asia Pacific Audiovisual Archives Association (SEAPAVAA). The PIA-MPD's highly-respected film production, post-production, and preservation capabilities meant that it was in a unique position to aid the efforts of the SOFIA-led AV archive movement. As discussed in the essay's penultimate section, the absence of an archival mandate for the PIA means that its archival film preservation and restoration efforts were vulnerable to abrupt closure. Indeed, the abolition of the PIA-MPD augured the end of the heyday of SOFIA's film restoration efforts. The fate of the MPD underscores the need for a firm legislative mandate for state agencies (such as the NFAP) explicitly charged with AV archiving.

This essay begins by reconstructing the itinerant institutional histories of key film collections hard-hit by the closure of the PIA-MPD in 2004. This is followed by a critical reflection on the sources and approaches deployed in this essay. Using a cultural policy approach alongside the insights of archival theory, feminist epistemology, and postcolonial historiography, I draw on an array of sources-legislative records, PIA documents, personal papers from members of SOFIA and SEAPAVAA, oral history interviews and archival films - to reconstruct the unwritten institutional history of several film collections that intersect with the fate of the former PIAMPD. What lessons should we take away from these various examples of 
the state-institutional contexts of Philippine cinema's archival fragility? The aftermath of the MPD's abolition underscores the drawbacks of a narrowly financial, profit-driven perspective on state film archiving that devalued analog cinema in relation to digital media while also ignoring the unique demands of AV archiving by conflating it with paper-based librarianship. Towards the end of this study, I affirm the Filipino AV archive advocacy's repeated calls for legislation to safeguard the institutional continuity and autonomy of Philippine film archives from the vagaries of political whim. I conclude by conceptualizing archival survival as not only involving the material preservation of analog or digital AV carriers but as also entailing exhaustion and persistence on the part of film archivists who persevere in institutional archival conditions they work to change, despite having witnessed, in some cases, the painful eventual deterioration of valuable film collections they had struggled to preserve.

As Ray Edmondson ${ }^{12}$ emphasizes, every archive is a memory institution that also needs to remember and preserve its own history. The critically reflexive historiography of Philippine state film archives I attempt here is motivated by the conviction that "institutions...which are guardians of a nation's memory need to also preserve their own memory, to know how and why they have come to be what they are...It is fundamental to their ethos, identity and public accountability" (Edmondson, 2011, p. 5). In the Philippines, historical knowledge about film-related state institutions is neither readily available nor easily reconstituted. The history of the PIA film collection-and its entanglement with the vexed histories of other undervalued and underfunded film archives in the Philippines-affirms Edmondson's insight that the vicissitudes of memory institutions are subjected to end up defining the surviving heritage such institutions are mandated to preserve (2011, p. 6).

\section{Archival Fragility: \\ The fate of significant film collections at the PIA-MPD}

The abolition of the PIA-MPD had wide-ranging consequences for its one-of-a-kind film collection, which included 2,373 titles that ranged from experimental cinema to award-winning works, government media productions, and films from donor countries and agencies (Leguiab, 2004, p. 12). Significantly, the MPD's dissolution had negative repercussions on three key collections entrusted to the PIA: films from the National Media Production Center (NMPC); the Movie and Television Review and Classification Board (MTRCB); and LVN Pictures, a major film studio established in 1938. 
Upon its creation in 1986, the PIA became the repository of Marcosera government productions not archived elsewhere. Of particular historical value are the documentaries, short films, plugs, and stock footage produced by the NMPC, an agency charged with disseminating information about government programs to the public and implementing the state's development agenda through media. ${ }^{13}$ In 2014 , I had the rare opportunity to screen several NMPC productions intended to justify the imposition of Martial Law. Excavated from the Film Vault of the former MPD, four $16 \mathrm{~mm}$ propaganda films made in 1971-72 stood out: PFM's Declaration of Martial Law, The Threat...Communism, The Enemy from Within, and From a Season of Strife. The poor-resolution images of such surviving NMPC films testify to the institutional de-prioritization and underfunding of the PIA film collection in the aftermath of the MPD's dissolution. The print of From a Season of Strife, for example, which an NFAP inspection report describes as "actively decaying" (NFAP, 2017) ${ }^{14}$, documents the beginning of the First Quarter Storm on January 26, 1970 but leaves the pivotal violence of that incident off-screen. The framing of the relatively benign footage, which offers glimpses of Ferdinand and Imelda Marcos emerging from Congress and stepping into their limousine behind a wall of riot shields, omits the riot police's brutal dispersal of student demonstrators (Figures 4-6). Variously pink, orange, or faded gray, with occasionally distorted sound and jumpy frames, such propaganda films are vital to our understanding of Philippine history. The need to remember how the Marcos dictatorship strove to justify its repression of dissent is particularly urgent under the Duterte regime.

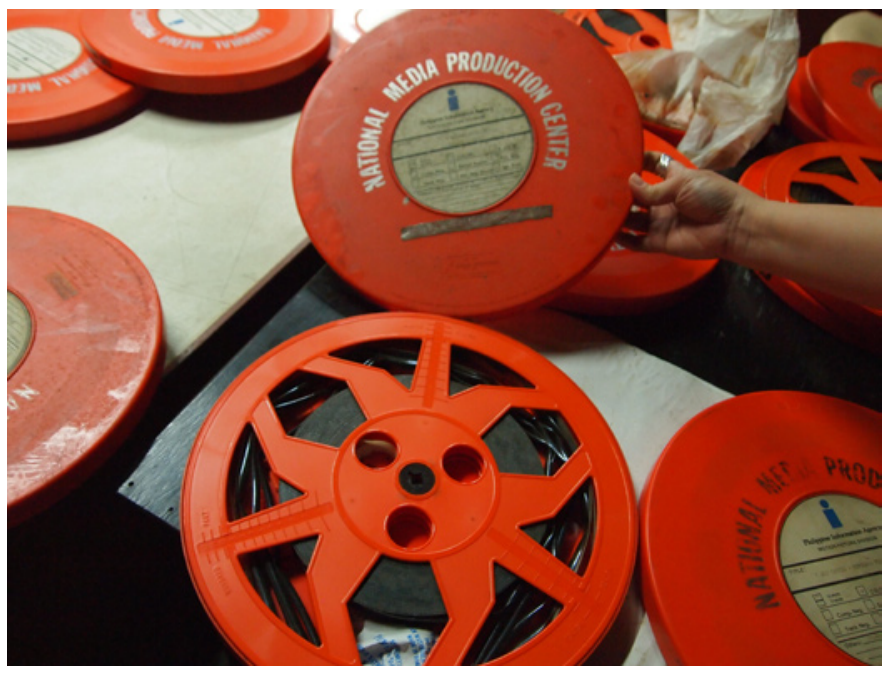

Fig. 4-6. Photo by author. 


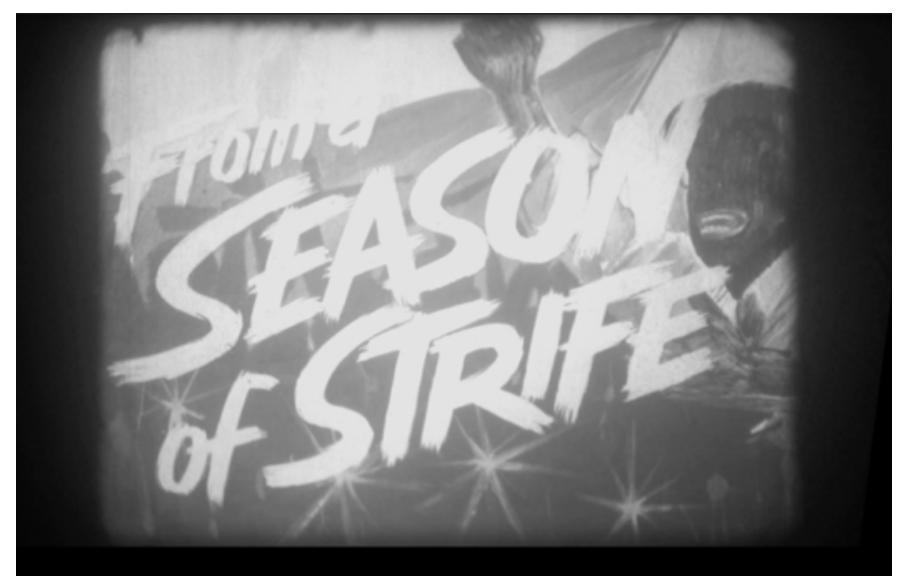

Fig. 5. Title card, From $A$ Season of Strife (NMPC, 1972).

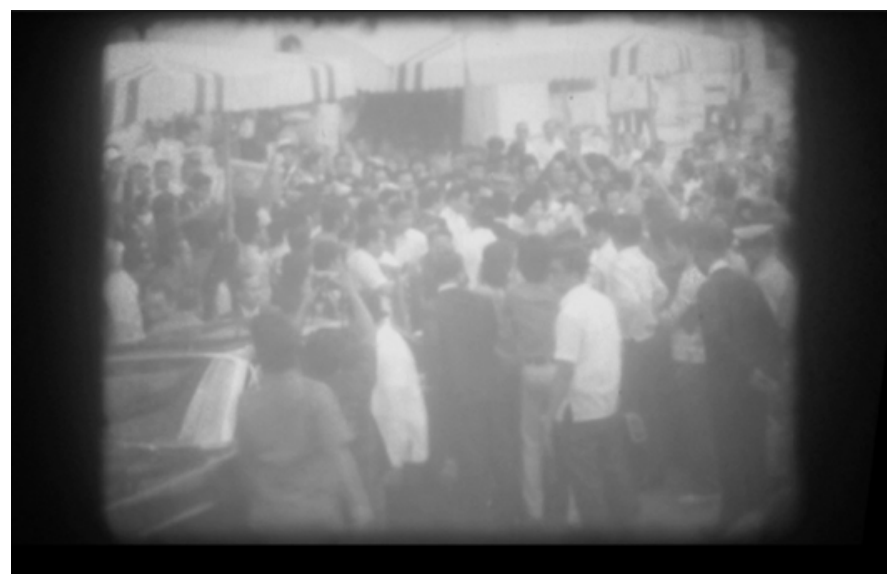

Fig. 6. The benign visual track of the NMPC propaganda film From A Season of Strife offers glimpses of Ferdinand and Imelda Marcos emerging from Congress on January 26,1970 , but leaves out the brutal dispersal of student demonstrators that sparked the beginning of the First Quarter Storm.

In addition to the NMPC's AV holdings, the PIA sheltered a second crucial film collection adversely affected by regime change: the imperiled remains of the defunct NFAP. Cory Aquino's administration failed to revive the NFAP despite NFAP Director-General Ernesto de Pedro's desperate plea for funding and support in a government report (de Pedro, 1986). As such, 1986 marks the beginning of a 25-year gap between the demise of the first NFAP and its long-awaited revival in 2011 during the term of Pres. Benigno "Noynoy" Aquino; much of Philippine film history was irretrievably lost in those gap years. After the Marcos regime was deposed in 1986, the valuable holdings of the defunct NFAP were caught in the uncertain transition between Marcos-era cultural institutions and the new film entities created by Cory Aquino's administration. Dispersed among various state entities with little direct connection to film archiving (the Experimental Cinema of the Philippines [ECP], the Manila Film Center, and the MTRCB), the NFAP's collection was whittled down by attrition and deterioration. ${ }^{15} \mathrm{In}$ 
1999, the MTRCB's film holdings-214 titles composed of 1,583 reels of 16 $\mathrm{mm}$ prints and $35 \mathrm{~mm}$ prints and negatives-were deposited at the PIAMPD for safekeeping (MTRCB-PIA, 1999a, 1999b). ${ }^{16}$ The PIA had, by way of the MTRCB, inherited endangered surviving fragments of the former NFAP collection that found their way to the MPD's custody over a decade after the overthrow of the Marcos regime.

In the Sisyphean history of Filipino film archiving, no rescued film is guaranteed a permanent safe harbor. This is one of the most painful lessons one gleans from the intertwined histories of various endangered state film archives-the Marcos era NFAP (which withered after 1986), the MTRCB's Film Archives and Library Division (turned over to the PIAMPD 1999), and the MPD itself, whose abrupt closure in 2004 resulted in the decay of films entrusted to the PIA's care. In 2004, citing "streamlining and cost-cutting measures" (Velasco, 2004e), the PIA began the process of handing over the MTRCB Film Collections in its custody to the Cultural Center of the Philippines (CCP), the Movie Workers Welfare Fund (MOWELFUND), and the University of the Philippines (UP) Film Center (MTRCB-MOWELFUND, 2005a, 2005b). MTRCB holdings deposited in MOWELFUND were eventually transferred to the NFAP in 2012 (NFAP, 2013a). ${ }^{17}$

A third significant film collection under PIA's custodianship was decimated in the aftermath of the MPD's closure: a clutch of films by LVN Pictures that had been neglected by the once-powerful film studio. ${ }^{18}$ Film historian Clodualdo del Mundo Jr. (2004) recounts that in 1994, LVN decided to discard films by other production companies that had long remained unclaimed in its storage vaults. Only a handful of production outfits retrieved their films upon being notified of the purge; the rest of the films-over a thousand rusting cans of celluloid comprising 72 titles-were dumped in the studio's open basketball court and left exposed to months of sun and rain. Led by another film historian, Agustin "Hammi" Sotto, members of SOFIA mounted a coordinated effort to rescue these films. SOFIA and PIA-MPD archivists who inspected the salvaged titles identified 25 priority films for rescue; while some had completely printable and restorable elements, others were incomplete or unrestorable (del Mundo, 2004, pp. 16-17). Through SOFIA's intervention, the PIA-MPD agreed to shelter the neglected LVN films in 1994 (Sotto, 1994). To be fair, when SOFIA and LVN approached the PIA in 1994, it was only to provide "temporary shelter" for the rescued LVN films, many of which were already in an advanced state of decay. PIA ended up housing the LVN films for over a decade since a new NFAP failed to be established in the interim. 
The abolition of the MPD and the subsequent under-funding of the PIA's film collection meant that, by 2007, almost all of those rescued films had degraded past the point of recovery. In 2004, Bel Capul, PIA-MISD Staff Director and a member of both SOFIA and SEAPAVAA, wrote SOFIA to inform them of the dissolution of the MPD and to update them on the condition of the LVN film collection at PIA: "Most of the 72 film titles (comprised of 1,471 reels of master negatives, sound negatives and prints) which were transferred to PIA in rusty old cans [in 1994] were irretrievably lost and already in different stages of deterioration at that time. Only about $3 \%$ of these transferred films have survived." Capul was writing to "request SOFIA to seek clearance from LVN to dispose [of] the lost films and [to arrange for] the transfer of the remaining $3 \%$ of the films to other archives who may be willing to temporarily host them pending the establishment of the national film archive" (Capul, 2004). I found no reply from either SOFIA or LVN among the PIA files I perused. Three years later, in 2007, Capul informed LVN that that by that point, $99 \%$ of the LVN films deposited at the PIA in 1994 had already deteriorated beyond repair. Capul was no longer asking for permission to transfer a small clutch of surviving films to another archive, she was asking for clearance for PIA to discard nearly the entire LVN collection at the PIA. Unable to make other arrangements for their films (the revival of the NFAP was still several years away), LVN approved the disposal of the vast majority of the films rescued from their backlot in 2008 (Capul, 2004; Capul, 2007; Eraña, 2008). ${ }^{19}$ The characteristically clipped, neutral tone of such institutional correspondence is profoundly at odds with the tragic content of these letters, with Capul, who had been instrumental to the rescue of these films, penning the very letters that ask LVN to dispose of the salvaged reels.

The demise of the majority of the LVN collection stored at PIA's film vault is a microcosm of the larger condition of archival fragility in the Philippines. Whether they miraculously survived the collapse of the first NFAP in 1986 or were recovered from a heap of rusted film cans in 1994, few rescued Filipino films enjoy permanent institutional protection from the ravages of decay. In 2013, Benedict "Bono" Olgado, Head of the NFAP at that time, identified key heritage films in the PIA collection and requested the immediate transfer of 52 titles (525 cans of $16 \mathrm{~mm}$ and $35 \mathrm{~mm}$ film) to the NFAP (Olgado, 2013); this was also done in compliance with a presidential directive requiring government agencies to turn over their audiovisual collections to the NFAP (Aquino, 2012). The PIA film collection was subsequently turned over to the NFAP in four batches over 2013 to 2015 (Coloma, 2013; NFAP 2013b, 2014a, 2014b, 2015; PIA-FDCP, 2013a, 2013b). The former MPD's holdings are now housed in the NFAP's transitory storage facilities since the NFAP lacks a permanent repository for its collection. 


\section{On Sources and Methods: \\ Critical Vigilance, Paper Trails, and Situated Knowledge}

Infused with a "healthy and thoroughgoing suspicion of official state politics," as Jonathan Sterne puts it, cultural policy studies maintains that "the administration of culture is no small matter." A critical cultural policy studies approach is particularly appropriate to an analysis of government entities and officials who "understand culture itself as an object of administration" (Sterne, 2002, pp. 59-60, 70). Edmondson (2011) comes to a similar conclusion in his historiography of the National Film and Sound Archive of Australia's (NFSA) struggle to define its identity and achieve institutional autonomy through legislation. ${ }^{20}$ The NFSA's decades-long struggle confirmed the vulnerability of state film archives to the missteps of politicians and bureaucrats, and the importance of tenacious critical dissent in calling the questionable decisions of state officials into account:

[E]ternal vigilance is the price of preservation. The bureaucratic and political landscape can change quickly. The official guardians of the national heritage and its custodial institutions cannot unfailingly be relied upon to fulfill their duty of care. Nor, when they fail, can they be easily brought to account. The system is not self-correcting. Ultimately, cultural institutions are public property and national treasures, and there is a wider duty of cultural stewardship shared among those who create the content of collections, those who curate and preserve them, and those who use them. The ways of expressing this stewardship will vary, but it will include the support and advice of professional and advocacy groups, and when necessary may require their open and persistent dissent. (Edmondson, 2011, p. 374)

The Philippine experience of film archiving underscores the need for accountability on the part of "official guardians of the national heritage and its custodial institutions" and the value of vigilance among those who care about and benefit from memory institutions devoted to cinema. At stake in this vigilance is the broader effort to transform what we do with and what we do about Philippine AV archives. Heeding Kathryn Pyne Addelson's work on the relevance of feminist epistemologies to public policy, my scholarship endeavors to make Philippine film archiving's predicament visible as an urgent public problem and to intervene in the ensuing arena of conflict that my own work and that of many others before me have constituted (Addelson 1993, pp. 276-279), fully aware that it takes time for an archival consciousness, advocacy, and political support to take hold (Edmondson, 2016, p. 33). 
With regards to source documentation for this study-published materials and legislative records circulating in the public sphere, the so-called "gray literature" of unpublished internal reports and memoranda, ${ }^{21}$ personal papers collected by insiders to these institutions, ${ }^{22}$ and oral histories-I adhere to the methodological principle that scholarship must be alive to the tension between "the institution as it wants to be seen," "the institution as others see it," "the unpublished record," and the "personal recollections of those involved" (Edmondson, 2011, pp. 8-9). I take it as axiomatic that "memory resides not just in things, but in people" (Edmondson, 2016, pp. $81)$.

In addition, my study adopts the approach that media historian Lisa Gitelman describes as the process of "following documents", which traces "techniques of control" while also probing the various demands that social actors negotiate in institutional contexts (Gitelman, 2014, p. 19). Documents are a vernacular genre of many types, encompassing memos and menus, contracts, and birth certificates. They serve purposes of evidence and accountability through their core logic, what she calls every document's "know-show function, since documenting is an epistemic practice: the kind of knowing that is all wrapped up with showing, and showing wrapped up with knowing." Rarely-accessed documents stored for reference at some later date also have a corollary function: "Closely related to the know-show function of documents is the work of no show, since sometimes documents are documents merely by dint of their potential to show: they are flagged and filed away for the future, just in case" (Gitelman, 2014, pp. 1-2). Having pored through several Philippine presidents' executive orders regarding cinema as well as PIA circulars and memoranda of agreements, I concur with Gitelman that documents carry the cultural weight of bureaucratic authority, reflecting the power and control of state officials but also opening the door to accountability (2014, pp. 4-5).

When, in 2008 and 2010, Mary del Pilar of ABS-CBN ${ }^{23}$ and Vicky Belarmino $^{24}$ of the CCP lent me dog-eared paper files they had collected during their early years with SOFIA and SEAPAVAA-brown Manila envelopes stuffed with an assortment of documents they had filed away, just in case-I promptly photocopied these, and cannot now remember whether and how many of these personal papers were published "originals", dotmatrix printouts, or photocopies themselves. What Gitelman accurately describes as the taken-for-granted concept of xerographic reproduction and the more recently naturalized ubiquity of digital scanning makes it hard for me to pinpoint exactly when, over the last decade, I scanned those photocopies into portable document format (PDF). The same goes for hard and soft copies of MPD and MISD documents I accessed with 
the assistance of Bel Capul ${ }^{25}$ and Vicky Bejerano ${ }^{26}$ at the PIA from 2014 to 2016. In working with such sources, I was participating in practices of documentary reproduction (Gitelman, 2014, pp. 84-85). Paper is the documentary medium par excellence (Gitelman, 2014, p. 3), so a materialist approach to media historiography recognizes that the institutional history of the PIA film collections recounted here involves institutional thinking about one medium (film) documented in and through another (paper), then remediated to PDFs on my laptop (digital format encountered through a software application).

While sharing early drafts of my work, I was asked by two supportive interlocutors why I so prominently acknowledge the names of the archivists I have encountered; one of these, an anonymous reader for this journal, asked whether my account of the archival situation, in drawing on archivists' standpoints, might sacrifice objectivity. I realized immediately that my answer to both questions was rooted in some of the deepest commitments that undergird this research and the formative influence of both postcolonial historiography and feminist epistemologies (particularly the generative conversations between figures like Donna Haraway, Sandra Harding, and others in the early 1990s) on my scholarly practice. I will do my best to summarize those epistemological premises and their implications for the stakes and approaches of my research here.

I adhere to those strands of feminist epistemologies that work toward no-nonsense, necessarily incomplete accounts of the worlds we live in that are nevertheless reliable because such situated knowledges can be held accountable for their claims (Haraway, 1991, p. 187). I name various social actors in the Philippine AV archive world, as well as the archives I've consulted, so that these power-differentiated sources (as well as my translations and interpretations of these) can be tracked. Objective scholarship is characterized by locatable, responsible assertions; it also candidly acknowledges "the critical and interpretive core of all knowledge" (Haraway, 1991, pp. 190-191). In speaking frankly about situated knowledge and multiple standpoints, feminist epistemologies have emphatically not given up objectivity in favor of relativism. (For what good would a free-for-all descent into relativism, in which all claims are equivalent, be for feminism and other social movements interested in a critique of subjugation? Whose interests, after all, do "fake news" serve?) What the feminist reconceptualization of objectivity gives up-illusory claims to innocence, totality, and universality, or what Haraway calls the "Godtrick" of bogus omniscience-it gains in accountability. This is one of the advantages of feminist thinkers' attempt to forge "a usable doctrine of 
objectivity" (Haraway, 1991, p. 189).

The impact of feminist epistemology on archival theory is evident in the work of Joan Schwartz and Terry Cook, who argue for the recognition that "archives...are not passive storehouses of old stuff, but active sites where social power is negotiated, contested, confirmed. The power of archives, records, and archivists should no longer remain naturalized or denied, but opened to vital debate and transparent accountability." In their challenge to the "professional myth of impartiality" in archival theory, Schwartz and Cook draw on Haraway's reconceptualization of objectivity, not as detached observation, but as the reflexive acknowledgement of the contexts and power dynamics shaping every person's situated perspective (Schwartz and Cook, 2002, pp. 1, 9, 12). While prime movers of the decentralized AV archival advocacy movement in the Philippines have included both straight-and-queer-identified men and women, female middle managers at both state and private AV archives have been especially pivotal for my research. The centrality of women archivists' perspectives to this project and the historically feminized labor of archiving (imagined in Schellenbergian archival theory as a "handmaiden" to the masculine enterprise of historywriting) make feminist analyses of knowledge production particularly germane for my work (Cook 2011, pp. 608-609; Cook, 2013, 107).

It is risky to try to speak reliably about real-world crises and an unfolding history of the present while acknowledging that all knowledge is inevitably fragmentary and situated. Researchers can only take a stab at responsible accounts of real events to the degree that we acknowledge the situatedness of our perspectives and attempt from there to share knowledge in a way that transforms the world, hopefully creating what Haraway calls "a chance for a future" (1991, p. 187). The task, which demands laying my cards on the table as I've attempted to do here, intimidates me. I am neither a historian nor an AV archivist by training. I am a film and media scholar who, by virtue of my dependence on archival materials-from analog to digital, from print to audiovisual-is a stakeholder in and advocate for Filipino AV archives, writing in the wake of a decentralized AV archival advocacy movement that dates from Ben Pinga's writings in the late 1950s to SOFIA-led initiatives from the 1990s and 2000s (Capul, 1997, 2000; Lim, 2013a; Mendoza, 1999; Pinga, 1956, 1968).

Reflecting on postcolonial historiography through the lens of the Haitian Revolution, Michel-Rolph Trouillot conceptualizes "subjective capacity" as central to the production of historical knowledge. To regard people as subjects means to recognize them as "voices aware of their vocality," or, put another way, as "purposeful subjects aware of their own voices." Trouillot teaches me two key points. First, that the subjective 
capacities of the players involved in historical events are vital rather than incidental to our understanding of history (Trouillot, 1995, pp. 23-24); reading Trouillot alongside archival theory, I realize that the subjective capacities of players in the Philippines' archival world must be understood as a (largely overlooked) form of archival power. Second, Trouillot's work persuades me of the impossibility of the "nonhistorical observer" fantasized by a positivist model of history that imagines an unmarked position for the historian. In contrast, Trouillot notes that historians (whether professional or amateur-and I count myself, of necessity, among the latter) are called to "position themselves more clearly" in the controversies of their own unfolding present (Trouillot, 1995, pp. 19-21, 151-152).

Feminist epistemologies and postcolonial historiographies were key to my graduate school training decades ago; through such lenses, I've learned to see the claims, interests, and concerns of socially-stratified historians, knowers, and doers as inherently situated, shaped by power relations and by historical and social contexts (Harding, 1993, pp. 60-61; Trouillot, 1995, p. xix). Over the course of my research, I gradually came to recognize that the standpoints of AV archivists on the collections they watch over and mediate have been largely overlooked in my own academic discipline, film and media studies, and undervalued in cultural policy decisions affecting the fate of Philippine cinema's troubled archives. This is likely due to a confluence of bureaucratic hierarchies (in which the administrative decisions of top officials take precedence over the recommendations of middle managers and staff) and the separateness of the disciplines of film and media studies from the world of archival collection management and preservation (a regrettable parochialism that has begun to be overcome in the last two decades). ${ }^{27}$ Similarly, although the writings of Jacques Derrida and Michel Foucault have spurred an archival turn in philosophy and critical theory, Cook points out that a great deal of theoretical and historiographical writing on archives has largely ignored the perspectives of professional archivists themselves (Cook 2011, pp. 614-615). AV archivists are a relatively tiny class of memory professionals (globally, their number "barely reaches five figures"), but these undervalued cultural workers wield a great deal of power over our collective memory (Edmondson, 2016, p. 82). The belated revaluation and integration of archival knowledge into film and media studies in general and into Philippine film scholarship specifically are themselves historically emergent (as the publication of this groundbreaking Plaridel issue attests).

A way forward, a chance for the future of Philippine film archives, seems to me premised precisely on drawing from, translating, and interpreting (rather than claiming to transparently speak for) the experiences, knowledges, and 
advocacies of the heterogeneous individuals and communities who work with endangered AV archives in the Philippines. One such significant yet especially vulnerable AV collection was that of the PIA-MPD, to which I now turn.

\section{"Fade Out: Motion Pictures Division; Fade In: Management Information System Division"}

On the eve of its abolition in 2004, the MPD was "PIA's largest division" and one of its most prestigious units. Its 42 staff members accounted for $14 \%$ of the Central Office personnel, while its floor area (2,379 sq.m.) occupied $32 \%$ of the agency's total office space. According to Capul, the PIA-MPD was a "one stop shop for [everything from] production to post-production. Our [Film] Lab had the reputation for [film] processing of international standard" (Capul, 2014), handling footage from major Hollywood films such as Francis Ford Coppola's Apocalypse Now (1979) and Oliver Stone's Platoon (1986) and Born on the Fourth of July (1989) (Leguiab, 2004, p. 12). Pioneering the art of archival film restoration in the Philippines, the MPD restored a total of 22 historic Philippine films in collaboration with the National Commission for Culture and the Arts (NCCA) and SOFIA, the most prominent of which are two of the five surviving prewar films, Tunay Na Ina and Giliw Ko (both from 1938), and Gerardo de Leon's acclaimed Noli Me Tangere (1961). Despite its eminent track record, the PIA-MPD was dissolved on the grounds that its film production and restoration facilities were "difficult to sustain financially" and that MPD resources were "underutilized" (Leguiab, 2004, pp. 12-13). A PIA publication articulated the rationale for the cutbacks: "To cope with the hard times, the government had to resort to some measures, often radical. Cost-cutting and streamlining were the measures employed by the government along with optimization of funds to favor high-impact projects. Indirectly, part of the process was the dissolution of the MPD" (Leguiab, 2004, 13)..$^{28}$

The closure of the MPD (centered on photochemical cinema) to make way for the creation of a new unit, the MISD (focused on digital information management), ${ }^{29}$ was rapidly accomplished across four PIA circulars issued from March 8 to April 29, 2004. Director-General Velasco's first circular, dated March 4th of that year, created a review committee that would "evaluate the functions of the Motion Picture Division and recommend measures to maximize the utilization of its existing resources" (Velasco, 2004b).

Notably, Velasco's second circular-which possibly announced and justified the consequential dissolution of the MPD—cannot be located by the PIA Records Section despite persistent search requests by MISD 
staff (Aragones, 2017). In lieu of this missing circular, I reconstruct the PIA bureaucracy's reasons for shutting down the MPD through surviving circulars and an article entitled, "Fade Out: Motion Pictures Division, Fade In: Management Information System Division", from a 2004 issue of the PIA newsletter, Tinig (Figure 7). Judging from its mode of address, the article aims to assuage the anxieties of PIA employees affected by the restructuring. Tinig is likely to have circulated internally within the PIA and possibly interorganizationally among other government agencies.

The Tinig article takes an upbeat view of the profound organizational overhaul of the PIA resulting from the dissolution of the MPD and the concomitant creation of the MISD. Laying responsibility for the dissolution at the feet of the review committee, the article reports that the MPD "will be dissolved as recommended by a committee review", resulting in the "transfer and merging of its production function to the [National] Broadcast Division", while the MPD's library holdings are to be "integrated [with]in the newly
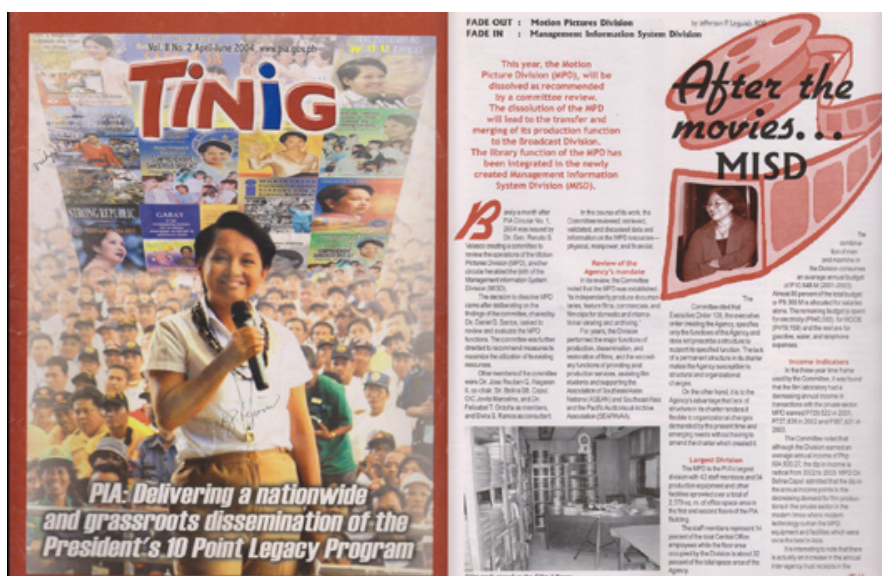

Fig. 7 A 2004 issue of Tinig, the PIA newsletter, discussed the rationale for the dissolution of the MPD and the creation of the MISD.

created Management Information System Division (MISD)" (Leguiab, 2004 p. 11).

In reading Tinig's coverage of the closure of the MPD to make way for the MISD, I adapt media industries studies scholar John Caldwell's critical perspective on the "managed self-disclosures" of studio executives and film industry personnel. Caldwell writes:

Media industry scholars face many challenges, but one of them is clearly not a lack of information about media industries. The question instead becomes: how does one intelligently unravel the many cultural, conceptual, economic, corporate, social, professional, and interpersonal 
strands of self-disclosure that are constantly thrown at viewer and scholar alike as part of industrial habit? (Caldwell, 2009, p. 199)

In what follows, I adapt Caldwell's industry and production studies perspective to think about the Tinig article as an instance of managed selfdisclosure on the part of a Philippine state institution. Since institutional realities, like industrial ones, are always multiply constructed, an analysis of PIA's own self-representation and self-reflection involves "cross-checking sources" (e.g., juxtaposing the claims of the Tinig article with the PIA circulars it references and interviews with archivists from MISD and the former MPD); taking nothing at face value; and exploring areas of tension, contradiction, and debate (Caldwell, 2009, pp. 201-203).

Read through this critical lens, the primary rhetorical objectives of the Tinig article are justification and reassurance with regards to the major changes triggered by the dissolution of the PIA's largest unit. The article seeks to justify the closure of the MPD on the grounds that during its last three-year period (2001-2003), the MPD yielded "decreasing annual income in transactions with the private sector", a steep drop in loans from the film library (although loans of stock footage remained strong), and decreasing film restoration work. ${ }^{30}$ "With the above figures, the Committee noted that the outputs/services of the MPD could hardly justify its manpower...,its total space area..., and its huge financial resources [e.g., its P10.948 M average annual budget]. Thus, the Committee decided, the resources of the MPD are underutilized" (Leguiab, 2004, pp. 11-12). In an interview, Capul refutes the financial rationale for the dissolution of the MPD: "They claimed a lack of funding...but I'll tell you that while we had funds allotted solely for laboratory film processing in the GAA [General Appropriations Act under the Department of Budget and Management], we never touched that because we lived on income from the inter-agency film productions commissioned by other government agencies" (Capul, 2014). ${ }^{31}$ Capul's contention is corroborated by the Tinig article, which notes that the $\mathrm{PhP} 372 \mathrm{~K}$ decrease in private sector transactions over this period was compensated for by a dramatic PhP 8.44 M increase in inter-agency income from film services from other state entities. Tinig remarks: "This means that although the demand for film services from the private sector decreased, the income generated from the inter-agency transactions dramatically increased thereby, suggesting increasing utilization of the film lab facilities for government projects" (Leguiab, 2004, pp. 12).

Alongside its justificatory objective, the second aim of the article (highlighted by the subheading, "DG Velasco's reassurance") is to assuage possible concerns among MPD staff by pledging that "there would be no 
reduction or demotion in rank as well as no reduction in compensation for the personnel of the Division" (Leguiab, 2004, pp. 11-12). In its unfailingly optimistic tone, the Tinig article reads like internal PIA propaganda seeking to forestall resistance or anxiety to the sweeping institutional overhaul about to take effect. The hyperbolic tone of the article's conclusion, for example, strikes an inspiring note while directly addressing MPD staff members facing redeployment or compulsory retirement: $:^{32}$ "As for the employees affected by the reorganization, a moment will come when they can regale in the fact that they have sacrificed, have toiled, and have taken part in furtherance of the grand design to achieve a more efficient and effective delivery of public service" (Leguiab, 2004, p. 13).

Capul recalls the MPD closure's impact on personnel in less sanguine terms: "Our film production people, those working in the laboratory, were all retooled. Engineers, for example, were sent to computer centers to acquire new skills. Our film restorers were retooled for the digital world. Those who were able to survive are still around... But some of the people in the laboratory, especially those older restorers who were really skilled, say at repairing film sprockets, were rather old to be retooled" (Capul, 2014). Thus, while some former MPD personnel were transferred to the newlycreated MISD or retrained to acquire new skills, highly-skilled motion picture restorers considered too old for such "retooling" were forced to retire, resulting in a loss of valuable competencies for the country's archival film preservation initiatives. It is now widely-recognized that the handson knowledge of seasoned archivists is indispensable; it is not only legacy media (obsolescent carriers and formats) but also legacy skills (expertise in outdated media) that need to be preserved to maintain "contextual integrity" (Edmondson, 2016, p. 26). By 2014, the PIA (Southeast Asia's premier film restoration lab in the 1990s) no longer had a single employee comfortable with projecting the $16 \mathrm{~mm}$ and $35 \mathrm{~mm}$ films in its collection, though the agency's film projection equipment remained in good working order. ${ }^{33}$

The most striking instance of internal contradiction within the article emerges in its reportage of the decision to shut down the Motion Picture Division under the section heading, "PIA Circular No. 3":

\section{PIA Circular No. 3}

The [MPD review] committee recommended two options for the management: (1) to fully rehabilitate the division, which would entail capital infusion to upgrade its equipment and facilities to be at par with the present standard; or (2) to dissolve the MPD in its entirety and transfer its production function to the Broadcast Division. 
PIA Circular No. 3, Series of 2004, dated April 26 articulated the management's option. (Leguiab, pp. 12, my emphasis)

The actual text of Velasco's third circular, however, contains no mention of the first recommendation of the MPD review committee reported by the Tinig article-i.e., to allocate greater funding to the MPD in order to "rehabilitate" its "equipment and facilities to be at par with the present standard." As Tinig noted, paraphrasing Capul, the downturn in the MPD's private sector income was caused by both the "decreasing demand for film productions" and the fact that MPD's once cutting-edge equipment and facilities were outdated and in need of an upgrade (Leguiab, 2004, p. 11). The closure of the MPD, as another subheading of the article emphasized, was "not a reflection of non-performance" on the part of MPD personnel but was due to the fact that "its equipment and facilities [had] seen better days" (p. 13). In short, the recognition that the MPD's outdated technology would eventually undermine its income-generating capacity strongly suggests that the PIA needed to allocate more resources to this historically high-performing, high-profile unit, not less.

For the most part, the Tinig article attempts to present the closure of the MPD as inevitable, that is, as a mere implementation of an impartial MPD review committee's findings. On the contrary, however, the review committee's first recommendation had not been to shut down a major division with a highly-regarded film lab and film archive, but to infuse it with capital. A technologically-upgraded MPD might have become more efficient and competitive in a hybrid, transitional moment when established photochemical cinema and digital information technologies were merging. Choosing to overlook the committee's first recommendation to upgrade the MPD through capital infusion, the PIA management instead decided to shut down an internationally recognized unit that employed the largest number of its personnel and was as old as the agency itself. As Edmondson remarks with poignant clarity, "What can take decades of effort to create can also be quickly unmade by the stroke of a bureaucratic pen" (Edmondson, 2011, p. 375).

\section{Lessons Learned from the Fallout, Or, What is to be done?}

The 2004 dissolution of the MPD destroyed not only its production and post-production capabilities but also the archival film collection that those competencies actively preserved. When asked about the consequences of the MPD's abolition, Capul noted the loss of financial and staff support for its archival storage facilities as well as a loss of promotion and circulation for its collection (Capul, 2014). Once housing a well-known film archive whose titles circulated through well-publicized exhibitions, the PIA's public- 
facing film initiatives ended with the MPD's closure. The MPD's dissolution squandered the considerable status and authority it had amassed over time, both indispensable attributes for AV archives that must win the public's trust in their institutional permanence (Edmondson, 2013, p. 25; 2016, p. 36). The aftermath of this significant state film archive's demise is a cautionary tale with several important takeaways.

First, AV archiving must be recognized as distinct from traditional librarianship centered on paper-based collections; failure to do so can unwittingly wipe out a film collection. PIA Circular No. 4 creating the MISD charged the new unit with "operation of the PIA Library and integration of all PIA document collections in print, film, video, photo, and slides" (Velasco, 2004d); in so doing, it unceremoniously incorporated the PIA's film collection with the rest of its print library. As a UNESCO report emphasizes, "audiovisual recordings are particularly vulnerable and require special attention for their long-term security" (UNESCO, 2006 p. 2). Equating film archives with other "document collections"-for which books and print materials are the primary point of reference-disregards the specific requirements of AV preservation and can instigate the gradual decline of film holdings. The Philippines has a tropical, maritime climate characterized by high temperature and humidity and plentiful rainfall (PAGASA, 2017). In contrast, conservation of analog AV media like photochemical film demands storage conditions in which temperature and humidity are carefully regulated. For their part, digital AV media require not only management of individual carriers (such as DVDs) but also monitoring of the stored files' integrity (Edmondson, 2016, p. 46).

The directive to integrate the agency's AV holdings into the rest of the PIA Library inaugurated chronic underfunding and deterioration for the PIA film collection, since a climate-controlled environment is costly to maintain. ${ }^{34}$ Following the MPD's closure, the PIA's film holdings were stored in the basement and second floor of the PIA building on Visayas Avenue, Quezon City; the basement holdings were flooded during Typhoon Ondoy in 2009. By 2013, they had deteriorated to such a point that they were disposed of by the PIA (Bejerano, 2014). New inventories of the surviving PIA collection were prepared when the PIA's AV holdings were eventually transferred to the NFAP. ${ }^{35}$

Second, the fate of the PIA film collection underscores the dangers of a purely financial perspective on the nation's cinematic past combined with a short-sighted valorization of digital media to the detriment of analog AV collections. The twin justifications for the closure of the MPD were both financial and media-technological: the need for streamlining at a government agency and the growing dominance of digital media, which was 
perceived as rendering analog film superfluous. That the PIA's film collection should have been devalued due to the growing importance of information technology invites a revisionist reference to an old adage: those unaware of media history might be doomed to repeat it. Recall that the advent of acetate film led to the misguided destruction of early nitrate films; today, most early film titles exist only in video form, countless film reels having been melted for silver. In the Philippines, the state bureaucracy's narrowly monetary interest in the PIA film collection led to a deeply ironic situation in which a government archive (the PIA) devalued state film collections in its care (e.g., the NMPC and MTRCB-NFAP films) because they were considered to have little or no commercial value (cf. Steyerl, 2009, p. 6).

Digitization is not synonymous with preservation, since digital media become outdated even more rapidly than analog works do. As Karen Gracy notes, "While $35 \mathrm{~mm}$ film was the industry standard for over one hundred years," new digital formats are continually replacing each other. "In the last fifteen years there have been over twenty-five different professional, industrial, educational, and consumer digital moving image formats," which means that content must constantly be transferred and no single digital format or playback system can be considered a permanently durable medium. Although online streaming of movie files from sites like YouTube provide convenient access, the image and sound quality of such highly compressed files fall below preservation standards. Storing high quality uncompressed digital moving images is expensive, requiring massive amounts of storage and vigilant maintenance. This means that film preservation today is a hybrid affair, combining both photochemical processes to preserve the first hundred years of cinema as well as digital asset management (Gracy, 2007, pp. 37, 183-184, 216). Seen in this light, the closure of the MPD and the devaluation of its film collection in 2004 was the result of a flawed all-or-nothing logic in which the influx of digital media was perceived to render film entirely irrelevant. In contrast, Giovanna Fossati emphasizes that audiovisual media are "inherently transitional;" the analogto-digital transition demands to be recognized as only one of several other major shifts in film history (e.g., transitions to sound cinema, to color film stock, and to competition and convergence with television and new media). Seen in this light, the advent of digital movies does not spell the death of photochemical cinema but expresses the ontologically transitory character of media in general (Fossati, 2009, pp. 13-17). It follows that photochemical cinema is not worthless, just as digital media cannot provide an "ultimate format" for AV preservation purposes (Edmondson, 2016, p. vi).

Third, the posthumous fate of the MPD collection raises the issue of the government's role in archival film preservation, and calls attention 
to the problem of short-term presidential appointments to top posts at state film entities. As Head of the MPD, Capul recalls that she was outspoken with regards to the proposal to abolish the MPD. She recounts the following conversation with Director-General Velasco in Taglish: "Sabi niya, [and he was] very very clear, since I was fighting for [film] preservation [under the MPD], 'e, kung ang government nga hindi inaasikaso 'yan, why do you push for it? Sabi ko, 'sino ba ang government? It's people who are on top and who can do something"36 (Capul, 2014). Whether accurately recollected memory or embellished anecdote, this purported exchange distills questions of state custodianship over culture-specifically the Philippine government's historical failure to pay attention to, look after, and care about the nation's film heritage (all semantic valences of the Tagalog verb asikaso) - as well as issues of accountability on the part of state officials "who can do something" about film preservation. Later in the same interview, as I was explaining my view that the state should not be motivated solely by market forces but should also preserve and restore commercially unprofitable films of public interest, Capul responded: "In that sense I agree with you that remiss ang government in terms of appreciating that [the importance of film preservation]...market forces are talagang market forces, mga business-minded 'yan. Pero dapat nakikita talaga ng government 'yan [the public interest in film preservation] tapos nagkaroon $n g$ intervention. Parang 'yan ang mahina pa, mahina ngayon o wala. Lalo na, papalit-palit ang head of...yung mga leadership sa [government] organization na passing-by sila"37 (Capul, 2014). I interpret Capul's last sentence to be a recognition that the changeable (papalit-palit), short-lived ("passing") nature of presidential appointments to top leadership positions in key state film entities like the PIA and the FDCP has historically had adverse effects on film preservation efforts, since much depends on whether or not the appointed official recognizes the value of AV archiving. Indeed, one of the enduring problems bequeathed by the Marcos era to contemporary cultural policy is the practice of presidential appointments to film entities, which makes state AV archives extremely vulnerable to changes in presidential administration. ${ }^{38}$

Fourth, a partial solution to the above-mentioned difficulties lies in securing a firm legislative mandate to assure the autonomy of a national institution for audiovisual archiving, as has been noted by critiques of the problematic organizational structure of the present-day NFAP (Lim, 2013b, p. 27; Olgado and Roque, 2017) and the PIA's own lack of a mandate for film archiving (Aquino, 1986; Capul, 2014). The need for "a national policy for the preservation of moving images in the Philippines" was recognized in SOFIA's earliest policy papers (Mendoza, 1994). In a recent position paper, Olgado and Rose Roque call for an "act establishing 
an autonomous national audiovisual center" and "object to it being under the auspices of the Film Development Council of the Philippines" (2017, pp. 1,3). A legislative mandate that assures the autonomy and permanent sustainability of a national AV archive is the holy grail of the archive world, but few institutions actually enjoy this protection, as Edmondson acknowledges: "Unlike other major memory institutions, many of the world's audiovisual archives lack a statutory base, charter or equivalent authority which defines their role, their security and their mandate. They are therefore vulnerable to challenge and change, and their permanence can be illusory. This highlights the need to achieve appropriate decrees, laws, and long-term policies to sustain these institutions" (2016, p. 5). Since onthe-ground realities often mean that complete statutory self-governance for AV archives is often out of reach, Edmondson notes that, in practice, semiautonomy is the "desirable minimum". In practical terms, semi-autonomy for AV archives has multiple facets, such as a legal mandate to assure its "perpetual succession" and "arms-length funding" so that its projects, priorities, and decisions are not beholden to "external sponsors, authorities, or a parent organization." If an AV archive cannot be completely selfgoverning then it must be meaningfully consulted in governance. Crucially, "the archive [should be] led by a director or executive team with a professional background in the audiovisual archiving field" (Edmondson, 2016, pp. 4951). ${ }^{39}$ In Australia, the NFSA's path to autonomy confirmed in Edmondson's mind the need for it to be helmed by "experienced audiovisual archivists" rather than "career bureaucrats without curatorial backgrounds" (2011, p. 326). As should be clear from the institutional histories I've reconstructed in this essay, these conditions for semi-autonomous archival governance have not been met in important Philippine state archives devoted to film. When appointed officials to state AV archives lack a background in moving image preservation, meaningful consultation with experienced professional archivists at these institutions, whether at the middle management or staff level, is a vital safeguard against decisions that state bureaucrats without curatorial experience may implement without fully realizing the harmful effects such decisions may have on the media heritage in their care.

Afinaltakeawayfrom theabovediscussionis thatculturalstewardship and the duty of care over the nation's AV heritage, while vested in state memory institutions and the people who work there, implicates a broader public as well. Wider public support for the decentralized AV archive advocacy in the Philippines is an important long-term goal that cannot be achieved without giving the public straightforward, reliable access to state AV archives. Distilling the lessons of Australia's "sustained public campaign by advocacy groups" to achieve statutory autonomy for 
the NFSA, the 2004 Future of the Archive conference at Canberra asserted that cultural stewardship for national AV archives rests not only with the government but also with these archives' stakeholders, such as the media producers, researchers, curators, archivists, and professional associations who form every AV archive's broader community (Edmondson, 2011, pp. 238-239). In contrast, the de-funding and near-decimation of important state film archives in the Philippines have occurred largely out of the public eye. No strident public advocacy arose to take Filipino government officials to task; both the unremarked demise of the PIA film collection after 2004 and the withering of the first NFAP in the late 1980s went largely unopposed. Despite the decades-long efforts of SOFIA, lack of legislative support and public indifference to the Philippines' imperiled film archives persist.

Stakeholders for Philippine film archives, broadly defined as "those groups without whose support the organization would cease to exist", (Edmondson, 2011, p.46) have by and large included a core group of archivists, collectors, and film and television industry executives. My hunch is that a wider community of stakeholders for imperiled Philippine film archives has failed to emerge for several interrelated reasons, factors that include but cannot be reduced to the state of the Philippine economy. The long absence of a national AV archive in the NFAP's gap years means that, in turn, few members of the general public have been able to access such collections. Historically, then, no broad community has become accustomed to relying upon-nor appreciated firsthand the value of-archival film institutions in the Philippines. Without being readily and continually accessible to the public, the present-day NFAP (like its predecessor, the PIA-MPD) lacks a sizable base of users invested enough to advocate vigorously on its behalf in the public sphere. In the absence of convenient, long-running access to state film archives, those with a personal or professional interest in Philippine film history have turned elsewhere: to personal collections lovingly amassed by devoted film buffs; to the collections of private media conglomerates like ABS-CBN; and to films available online. The Philippines' tenacious-but insufficiently broad-based-archive advocacy movement is thus caught in a chicken-and-egg problem: lacking established, enduring archives, few stakeholders can be mobilized to press for an archive that endures. Absent a critical mass of users reliant on state media archives, a broadbased advocacy that demands legislated autonomy and sustainability for a national audiovisual institution has historically failed to coalesce.

\section{On Advocacy, Perseverance, and Survival}

Activists and stakeholders engaged in the long-haul struggle to secure the autonomy and sustainability of AV archives risk hopelessness and burn out. 
Writing of the NFSA campaign, Edmondson reflects: "For the advocacy groups, the risk was always one of exhaustion and despair about ever reaching their goal. That the campaign persisted for as long as necessary was in itself a major achievement" (2011, p. 356, my emphasis). In what follows, I link anthropologist Elizabeth Povinelli's reflections on activist perseverance to Edmondson's insight that persistence is itself an achievement in an inhospitable state context for AV archiving.

In Economies of Abandonment, Povinelli asks why some people are able to endure, that is, "to persist beyond the point of exhaustion for other people" under late liberalism. She explores this question by looking closely at an alternative social project in Australia that aimed to harness smartphone video cameras and GPS technology to actualize indigenous knowledge about culture and the landscape. Of several boat trips that she and her indigenous colleagues took on the Daly River for the Anson Bay Mobile Phone Project, Povinelli recounts a particularly hazardous trip on a 10 -foot dinghy in 2008. State and private corporate financing for the project were scant; the material conditions of their attempt to cross rough waters in order to reach Banagola, a beach on the southern shore of one of Daly River's estuarines, were far from ideal. The dinghy's motor, the only one the group could afford, was too weak to overcome the large waves; the boat itself was punctured and missing a paddle. This meant that the boat was, at times, in danger of capsizing, while those on board risked hypothermia and constantly collided with one another. Fuel was limited, and the food supply consisted of roadkill that hunters on board had brought for the trip (Povinelli, 2011, pp. 110-112).

Assessing their efforts, Povinelli (2011) writes:

We eventually made it to Banagula. On other days we don't make it back or do so barely. But we keep meeting and trying to raise resources to support the project. We are neither defeated nor are we successful. We persevere...[although] the actual lives supporting this ethical practice hardly seem sufficient to achieve its goals" (p. 115, my emphasis).

Despite federal legislation to recognize indigenous people's rights to selfdetermination in 1976, Povinelli notes that the conditions of indigenous life "in terms of health, education, wealth, life expectancy, and mental outlook" have barely been ameliorated and are still worse off relative to that of most other Australians (pp. 112-113). The lives of these activists and their families are thus marked by lower life expectancy rates, violence in their communities, and the threat that small infractions incurred in the course of the project might harden into a criminal record leading to incarceration. 
Over the years, the difficulties that her indigenous friends faced gradually reduced the number of people still involved in the project who were on the dinghy back in 2008. Povinelli's work, then, emphasizes the problem of enduring and the realities of depletion and attrition in real-world struggles (p. 116).

Povinelli's twin questions-how to endure as one strives to persevere, together with the effort to change the conditions in which one's persevering occurs (p. 103)-are extremely resonant for those who have lived through the demise of key film archives in the Philippines. Continuing to care for and care about Filipino AV archives requires "determination and optimism"two traits Edmondson saw as integral to the NFSA's struggle (Edmondson, 2011, p. 356). Like the story Povinelli relates about the diminishing collective of friends and fellow activists she collaborated with in Australia, the decentralized advocacy for a Philippine AV archive persists, but always risks doing so in depleted form.

Asfor the Australian state, a government that, after the 2007 Intervention, "refused to fund any projects that could not demonstrate a market outcome" (Povinelli, 2011, p. 115), and whose agents levied fines on Povinelli's group for their under-equipped boat's failure to comply with safety regulations (p. 119) - none of its actions amounted to the state's literal killing of the activists involved, although it made the path to their goals ever rougher and steeper.

In other words, those of us on the boat trying to cross Anson Bay are not being killed by the state in any way that would be recognizable as state killing. ... Most opposition to alternative social projects happens in a different way. An authorless wager is made that very few people will be able to continue to persevere in the face of prevailing material obstacles. They will not be able to sustain their perseverance. (Povinelli, 2011, pp. 118-119, my emphasis).

The notion of the state's authorless wager is profoundly relevant to the experience of SOFIA archivists who witnessed the death of the first NFAP as well as the demise of the PIA-MPD; who sheltered the rescued holdings of the LVN, only to see their efforts come to naught a decade later. From my ongoing conversations with seasoned Filipino film archivists since 2012, I come away with the impression that they are by turns frustrated, dispirited, and exhausted by the many struggles their advocacy movement has faced over the years. Yet they persevere, both within SOFIA and the various stakeholder institutions of AV archiving in the Philippines and Southeast Asia: the PIA, the CCP, the resurrected NFAP, MOWELFUND Film Institute, 
UP Film Institute, NCCA, and SEAPAVAA. Arrayed against them is an authorless wager, a bet no one in particular has placed. The authorless wager of the dominant is that under such conditions of precarity, the alternatives proposed will either not endure or never become ascendant, because the activists proposing this otherwise to the status quo will eventually become too exhausted to persevere.

This leads Povinelli's chapter to close on what I read as a note of political minimalism (as opposed to political utopianism): "This otherwise may lie in shattering the life-world in which a person finds herself situated, but it also might mean maintaining a life-world under constant threat of being saturated by the rhythms and meanings of another...In these situations, to be the same, to be durative, may be as emancipatory as to be transitive" (p. 130, my emphasis). This political minimalism suggests that under such "reduced conditions of life" (p. 128) (in this case, the lifespan of aging AV collections as well as the lives of cultural workers in a career-long struggle to preserve them), to merely have managed to endure might be viewed as a substantial accomplishment. This political minimalism-or minimal radicalism-does not demand success; recalling Edmondson's earlier quote on persistence as itself a "major achievement", it recognizes endurance and perseverance as both prerequisites for social and cultural movements as well as a limited, but not meaningless, accomplishment on the part of those activists and advocates who have neither won nor been vanquished across decades of under-funding and under-valuation.

To my mind, Edmondson and Povinelli's reflections on exhaustion and persistence open up multiply-posed questions of archival survival operating at various scales. From the 1980s to the present, the demise of key state film archives-the Marcos era NFAP and the defunct PIA-MPD - attest that in the Philippines, many significant film archives fail to survive, or are always on the verge of coming undone, their carefully accumulated collections becoming tragically re-dispersed as state-institutional supports fall away. This means that seasoned advocates who try to ensure archival survival have in fact already lived through the converse, having witnessed the closure of the first NFAP archive, or the PIA-MPD, or both. Though some early prime movers in the AV archive advocacy have since become inactive, those who persevere have likely come up with tactics to survive various state film archives' actual or imminent deaths. They have, in one form or another, grappled with the question of how to outlive a state archive's collapse; or, put differently, how to outlive the authorless wager of state indifference without the films degrading beyond repair and the archivist-activists themselves succumbing to exhaustion.

Survival is not just a question, then, of preserving deteriorating celluloid 
films from further decay, or of vigilantly and continually migrating digitallyborn films. Rather, it is also a question of surviving, by turns, the casual indifference, wait-it-out complacency, or pointed ill-will of the state. Under such circumstances, the Philippines' decentralized AV archival advocacy demands an activist form of enduring despite exhaustion on the part of behind-the-scenes cultural workers in beleaguered memory institutions. Archival survival is not the equivalent of a revolution in Filipino audiovisual archiving, an ideal, enduring, positive transformation in which Filipino film history is forever safeguarded by a beneficent Philippine state. On the ground, archival survival is closer to a politically minimal, non-utopic, non-idealized aspiration for the preservation of the Philippines' fragile AV archives, an aspiration forged by the lessons of various film archives' vexed institutional histories.

In the penultimate section of this essay and elsewhere, I've enumerated concrete measures that advocates for AV archives in the Philippines should continue to press for (Lim, 2013b). Chief among these is legislation that: 1. mandates the autonomy and perpetual sustainability of a national audiovisual archive; 2 . shields such an archive from missteps by short-term bureaucratic appointees through provisions for either self-governance or semi-autonomous consultative governance with the qualified archivists employed to staff and manage such an archive; 3 . secures funding to increase the numbers of plantilla positions for qualified archivists; ${ }^{40}$ and 4 . allocates funding for a permanent (rather than temporary) archival repository for the nation's AV heritage. Alongside these goals and priorities, however, I've also reflected on issues of exhaustion and burnout that all tenacious activists and advocates in a long-haul, uphill battle face. One modest aim of this essay has been to bring these largely unnoticed stories of archival loss and survival to light, cognizant that, in a worst-case scenario, such written histories of embattled Philippine film archives might one day outlive the imperiled works in these collections. A similar impetus to temper expectations animated this essay's acknowledgment of the necessarily situated, interpretive, and incomplete character of any historiography of the unfolding present. To have reconstructed the complicated institutional history of the posthumous PIA-MPD as it intersects with other state and non-governmental film entities might seem like too politically minimal an endeavor. Nonetheless, it discerns that the ground-level realities militating against the preservation of Philippine cinema are too thorny to be held to an impossible political-archival ideal. 


\section{References}

Addelson, K. P. (1993). Knower/Doers and their moral problems. In L. Alcoff \& E. Potter (Eds.), Feminist epistemologies (pp. 265-294). New York, N.Y.: Routledge.

Aquino, C.C. (1986). Executive order no. 100: Creating the Philippine Information Agency. Retrieved from http://www.officialgazette.gov.ph/1986/12/24/executive-order-no-100-s-1986/.

Aquino, B. S. (2012). Administrative order no. 26: Prescribing the rules on the deposit of copies of films and other audio-visuals to the National Film Archive of the Philippines. Retrieved from http://www. officialgazette.gov.ph/2012/04/17/administrative-order-no-26-s-2012/.

Bigourdan, J.L. (2000).Vinegar syndrome: An action plan. In The vinegar syndrome: A handbook, prevention, remedies and the use of new technologies (pp.45-59). Bologna:The GAMMA Group.

Bloomberg (n.d.). Executive Profile: Renato S. Velasco. Retrieved from https://www.bloomberg.com/ research/stocks/private/person.asp?personld=27615738\&privcapld=109370310.

Cabato, R. (2017, August 3). The state of culture under Duterte. CNN Philippines. Retrieved from http:// cnnphilippines.com/life/culture/arts/2017/08/03/the-state-of-culture-under-duterte-katrinastuart-santiago.html.

Caldwell,J.T. (2009). Cultures of production:Studying industry's deep texts, reflexive rituals, and managed self-disclosures. In J. Holt \& A. Perren (Eds.) Media industries, history, theory, and method (pp. 199212). MA and Oxford:Wiley Blackwell.

Capul, B. (1997, December). Annex H:Toward a national film archive for the Philippines. Paper presented at the Workshop/ Consultative Meeting on the Development Plan for AV Archiving in the Region: The ASEAN Catalogue of Film and Television Productions), Quezon City,

Capul, B. (2000). Evolving a National Focus Point for AV Archiving (Unpublished Conference Paper).

Capul, B. (2004, November 30). Letter from PIA-MISD Staff Director Belina Capul to SOFIA President Clodualdo "Doy" del Mundo. PIA-MISD Archives.

Capul, B. (2007, May 9). Letter from PIA-MISD Staff Director Belina Capul to LVN Pictures General Manager Nenita Eraña. PIA-MISD Archives.

Coloma, S. (2013, May 23). Re: Transfer of audio-visual collections of PIA to NFAP. Memorandum from PCOO Secretary Herminio "Sonny" Coloma. PIA-MISD Archives.

Cook. T. (2011). The archive(s) is a foreign country: Historians, archivists and the changing archival landscape. The American Archivist, 74, 600-632.

Cook, T. (2013). Evidence, memory, identity, and community. Archival Science 13, 95-120.

de Pedro, E. A. (1986, May 22). Overview of the Film Archives (Report for Hon. Joker C. Arroyo, Executive Secretary, from Ernie A. de Pedro, Director-General, Film Archives of the Philippines). Incomplete copy at PIA-MISD Archives.

Del Mundo, C. A. (1998). Native resistance:Philippine cinema and colonialism, 1898-1941. Manila: De La Salle University Press. PIA-MISD Archives.

Del Mundo, C. A. (2004). Dreaming of a National Audio-Visual Archive. Society of Film Archivists (SOFIA).

Deocampo, N. (2004, February). Zamboanga: 'lost' Philippine-made film discovered in US Archive. Movement, 2-7.

Deocampo, N. (2007). Cine: Spanish influences on early cinema in the Philippines. Pasig: Anvil Publishing. 
Edmondson, R. (2011). National film and sound archive: The quest for identity (Unpublished doctoral dissertation). University of Canberra, Australia.

Edmondson, R. (2013). Notes on sustainability of audiovisual archives. In Proceedings of the Philippine cinema heritage summit: A report (pp. 24-25). Manila: National Film Archives of the Philippines.

Edmondson, R. (2016). Audiovisual archiving: Philosophy and principles (3rd ed.). Paris and Bangkok: UNESCO.

Edmondson, R. \& Pike, A. (1982). Australia's lost films. Canberra: National Library of Australia.

Evangelista, P. (2018, February 23). The librarians: A Rappler profile. Rappler.com. Retrieved from https:// www.rappler.com/newsbreak/rich-media/196642-national-library-philippines-librarians-cesargilbert-adriano.

Fernandez, D. G. (1989). Mass culture and cultural policy: The Philippine experience. Philippine Studies 37(4), 488-502.

Film Heritage Foundation. (2018). Preserving our film heritage. Retrieved from http:// filmheritagefoundation.co.in/preserving-our-film-heritage/.

Fossati, G. (2009). From grain to pixel:The archival life of film in transition. Amsterdam: Amsterdam University Press.

Gaje, V. M. (2017, May 30). Inventory listing of the remaining audiovisual materials and equipment for deposit and/or transfer to NFAP. Memorandum from PIA MISD Officer-in-Charge, Virgilio M. Gaje, to PIA Director-General Harold E. Clavite. PIA-MISD Archives.

Galino, J. (2018, March 5). Phone interview with author.

Gitelman, L. (2014). Paper knowledge: Toward a media history of documents. Durham and London: Duke University Press.

Gracy, K. F. (2007). Film preservation: Competing definitions of value, use, and practice. Chicago: Society of American Archivists.

Graphic. (1968, December 18). The ABS-CBN Story, 44.

Haraway, D. (1991). Situated knowledges: The science question in feminism and the privilege of partial perspective. In D. Haraway, (Ed.), Simians, cyborgs, and women (pp. 183-201). New York: Routledge.

Harding, S. (1993). Rethinking standpoint epistemology:What is'strong objectivity'?.In L. Alcoff \& E. Potter (Eds.), Feminist epistemologies (pp. 49-82). New York, N.Y.: Routledge.

Junio, Mack. (2003). The movie in my mind: a film archivist's reflection. Philippine Audiovisual Archives Collections: An Inventory. NCCA-Committee on Archives \& SOFIA.

Kiernan, V. (1995). Preserving movies. Technology Review, 98(3), 14-16.

Leguiab, J.P. (2004). Fade out:Motion pictures division, fade in: Management information system division. Tinig, 2(2), 11-13. PIA-MISD Archives.

Lim, B. C. (2013a). A brief history of archival advocacy for Philippine cinema. Proceedings of the Philippine cinema heritage summit: A report (pp. 14-20). Manila: National Film Archives of the Philippines.

Lim, B. C. (2013b). Analysis and recommendations in the wake of the 2013 Philippine cinema heritage summit. Proceedings of the Philippine cinema heritage summit: A report (pp. 26-32). Manila: National Film Archives of the Philippines.

Mangahas, M. (2009, August 29). Gloria gets richer fastest, beats Cory, Ramos, Erap. Philippine Center for 
Investigative Journalism. Retrieved from http://pcij.org/stories/gloria-gets-richer-fastest-beatscory-ramos-erap/

Marcos, F. E. (1981). Executive order no. 640-a: Prescribing guidelines to promote and enhance the preservation, growth, and development of the motion picture art and science in the Philippines. Retrieved from http://www.officialgazette.gov.ph/1981/01/05/executive-order-no-640-a-s-1981/.

Mendoza, A. M. (1994, June 29). Draft elements for a master plan to save the Philippines' film heritage.

Mendoza, A. M. (Ed.) (1999). Seven years of the society of film archivists. Society of Film Archivists (SOFIA) Newsletter 1(1), 1,7.

Movie and Television Review and Classification Board \& Philippine Information Agency. (1999a, Oct 6). Memorandum of Agreement. PIA-MISD Archives.

Movie and Television Review and Classification Board \& Philippine Information Agency. (1999b, Sept 27). Annex A: Films transferred to the PIA. PIA-MISD Archives.

Movie and Television Review and Classification Board \& Movie Workers Welfare Fund. (2005a). Memorandum of Agreement. PIA-MISD Archives.

Movie and Television Review and Classification Board \& Movie Workers Welfare Fund. (2005b). Annex A: List of films to be deposited at the Cultural Center of the Philippines; List of films to be deposited at the University of the Philippines Film Center. PIA-MISD Archives.

National Film and Sound Archive of Australia. (n.d.) Base Polymers. Technical preservation handbook. Retrieved from https://www.nfsa.gov.au/preservation/guide/handbook/base-polymers.

National Film Archives of the Philippines. (2013a). NFAP annual report 2011-2012. Retrieved from https:// issuu.com/nfap/docs/nfap_annualreport_20112012. PIA-MISD Archives.

National Film Archives of the Philippines. (2013b, Aug 22). List of PIA film titles as deposited/ transferred to FDCP-NFAP. PIA-MISD Archives.

National Film Archives of the Philippines. (2014a, November 27 to December 1). NFAP Inventory List: Inventory of PIA Film Collections.

National Film Archives of the Philippines. (2014b, December 23). Inventory List-NFAP.

National Film Archives of the Philippines. (2015, April 28). NFAP (PIA) Initial inventory of 3rd batch (16 and $35 \mathrm{~mm}$ ) film inventory. PIA-MISD Archives.

National Film Archives of the Philippines. (2017, March 24). Film inspection and status report, PIA Collection.

National Film Archives of the Philippines. (as of 2018, February 20). MOWELFUND (NFAP inventory).

National Media Production Center, Office of the President, \& the Department of National Defense (Producers). (1972). From a season of strife [Motion picture].

Presidential Communications Reforms. (N.d.) Official Gazette of the Republic of the Philippines. Retrieved from http://www.officialgazette.gov.ph/featured/presidential-communications/.

Olgado, B. S. (2013, February 19).Letter from NFAP Head Benedict Salazar Olgado to PIA Director-General Jose Mari Oquiñena. Re: Request for transfer of key heritage Filipino feature films currently at the Philippine Information Agency archives. PIA-MISD Archives.

Olgado, B.S. \& Roque, R. (2017, May 17). A position paper on House Bill No. 2404, An Act Creating the National Film Archive to be Managed by the Film Development Council, and Appropriating Funds Therefor. PIA MISD Archives. 
PAGASA [Philippine Atmospheric, Geophysical and Astronomical Services Administration]. (2017). Philippine Climate. Retrieved from https://www1.pagasa.dost.gov.ph/index.php/27-climatologyand-agrometeorology

Patino, B. (2017, May 9). [Email from Bernadette Patino of NFAP to Benedict "Bono" Olgado.]

Philippine Information Agency \& Film Development Council of the Philippines (2013a, August 23). Memorandum of Agreement. PIA-MISD Archives.

Philippine Information Agency \& Film Development Council of the Philippines (2013b, September 23).

Annex A: Inventory of Deposited Materials from PIA to NFAP. PIA-MISD Archives.

Philippine Information Agency Management Information System Division. (1999 June). Status of MTRCB Film Archives and Library Division. PIA-MISD Archives.

Pinga, B. G. (1956). Report on Screen Education. Unpublished Typescript, Film Institute of the Philippines, Philippines.

Pinga, B. G. (1968). Looking at our Film Institute. Cinema Philippines, 5-9.

Povinelli, E. A. (2011). Economies of abandonment: Social belonging and endurance in late liberalism. Durham and London: Duke University Press.

San Diego, B. Jr. (2012, September 2). Genghis Khan, lost and found. Philippine Daily Inquirer. Retrieved from http://entertainment.inquirer.net/56568/genghis-khan-lost-and-found.

Schwartz, J.M \& Cook, T. (2002). Archives, records, and power: The Making of Modern Memory. Archival Science 2, 1-19.

Sotto, A. (1994, September 19). Letter to PIA Undersecretary Honesto Isleta.

Sterne, J. (2002). Cultural policy studies and the problem of political representation. The Communication Review 5, 59-89.

Steyerl, H. (2009). In defense of the poor image. e-flux, 10. Retrieved from http://www.e-flux.com/ journal/10/61362/in-defense-of-the-poor-image/

Streible, D. (2013). Moving image history and the $f$-word; or, 'digital film' is an oxymoron. Film History 25 (1-2), 227-235.

Trouillot, M-R. (1995). Silencing the past: Power and the production of history. Boston: Beacon Press.

Tuazon, R. R. (2015). Government media: Rewriting their image and role. Retrieved from http://ncca.gov. $\mathrm{ph} /$ subcommissions/subcommission-on-cultural-disseminationscd/communication/governmentmedia-rewriting-their-image-and-role/.

United Nations Educational, Scientific, and Cultural Organization [UNESCO]. (2006, September 1). Report by the Director-General on the Implications of the Proclamation of a World Day for Audiovisual Heritage. Paris. Retrieved from http://unesdoc.unesco.org/images/0014/001469/146936e.pdf.

Velasco, R. S. (2004a, March 8). PIA Circular No. 1. Review Committee for Motion Pictures Division. PIAMISD Archives.

Velasco, R. S. (2004b, April 26). PIA Circular No. 3. Implementation of the MPD-Related Management Committee Decisions by the MPD Review Committee. PIA-MISD Archives.

Velasco, R. S. (2004c, April 29). PIA Circular No. 4. Management Information System Division (MISD). PIAMISD Archives.

Velasco, R. S. (2004d, July 15). PIA Special Order No. 195. PIA-MISD Archives.

Velasco, R. S. (2004e, November 2). Letter from PIA Director General Renato S. Velasco to MTRCB Chairwoman Ma. Consoliza P. Laguardia. PIA-MISD Archives. 
Whaley, F. (2012, October 4). Philippines Ex-President is Arrested in Hospital on New Charges. New York Times. Retrieved from http://www.nytimes.com/2012/10/05/world/asia/philippines-ex-presidentarrested-in-hospital-on-new-charges.html

Whaley, F. (2016, July 19). Philippines Clears Gloria Macapagal Arroyo, Ex-President, of Graft Charges. New York Times. Retrieved from https://www.nytimes.com/2016/07/20/world/asia/philippines-gloriaarroyo-corruption-dismissed.html.

\section{Frequently used acronyms}

ABS-CBN-Part of the Lopez Group of Companies, ABS-CBN is a Philippine broadcast media whose origins date from the 1956 merger of the Alto Broadcasting System (ABS) with the Chronicle Broadcasting Corporation (CBN). (Graphic, 1968)

AV_-Audiovisual (cf. note 3)

CCP-Cultural Center of the Philippines

FDCP_Film Development Council of the Philippines

LVN_LVN Pictures, a major film studio founded in 1938 (cf. note 16)

MOA-Memorandum of Agreement

MOWELFUNDMovie Workers Welfare Foundation, Inc. (formerly Movie Workers Welfare Fund) MPD (or PIA-MPD)—Motion Picture Division of the Philippine Information Agency

MTRCB—Movie and Television Review and Classification Board

NCCA — National Commission for Culture and the Arts

NFAP_National Film Archives of the Philippines

NFSA - National Film and Sound Archive of Australia

NMPC — National Media Production Center

OMA-Office of Media Affairs

PCOO_Presidential Communications Operations Office

PDF_Portable Document Format

PIA_Philippine Information Agency

PIA-MISD—Management Information System Division of the Philippine Information Agency

SEAPAVAA - South East Asia Pacific Audio Visual Archives Association

SOFIA-Society of Filipino Archivists for Film (formerly Society of Film Archivists)

UNESCO-United Nations Educational, Scientific, and Cultural Organization

UP_University of the Philippines

\section{Notes}

1 The five surviving Filipino full-length feature films from the American colonial period, all produced prior to World War II, are: Zamboanga (1937), Tunay Na Ina (True Mother, 1939), Giliw Ko (My Dear, 1939), Pakiusap (Lover's Plea, 1940), and Ibong Adarna (Adarna Bird, 1941). (Del Mundo, 1998, pp. 7-8; Deocampo, 2004).

2 Julie Galino, former Film Archive Supervisor at LVN Pictures, recounts that although the nitrate dupe negative was still in good condition at the end of the restoration, a safe storage facility could not be found for it:LVN Pictures' laboratory closed in 2005, the PIA-MPD had been abolished the year before, and ABS-CBN's film archive declined to house nitrate in its vaults. Ibong Adarna's dupe negative, the last 
nitrate film in existence, the very element Arnulfio Junio mentioned in 2003, was disposed of shortly after the restoration (J.Galino, 2018).

3 Accurate, current data on surviving films worldwide are difficult to find; nevertheless, available information suggests that Philippine cinema's archival situation is comparatively worse than that of other nations. In 1995, a preservationist at the American Film Institute estimated that more than 50 percent of US nitrate feature films made prior to 1950 are in a deteriorated state, while fewer than $10 \%$ of nitrate cinema from the 1910 s survive (Kiernan, 1995, p. 14). According to a 1982 monograph, 50 Australian silent films made earlier than 1930 survive in whole or in part (Edmondson and Pike, 1982, p. 9) while India, which has lost $90 \%$ of its 1,700 domestically-produced silent films, can still claim " 5 to 6 complete films and 12 to 15 film fragments in the archive" (Film Heritage Foundation, 2018).

4 Audiovisual (AV) is an inclusive term for moving images and recorded sound across a range of media, formats, and carriers (the physical objects, such as vinyl records, nitrocellulose film, videotapes, DVDs or Blu-ray discs, on which audiovisual content is recorded or stored). Film, used in a narrow technical sense, denotes negative or positive film strips coated with light-sensitive emulsion, either used in still photography or in photochemical (analog) cinema (Edmondson, 2016, pp. 19-20). Historically, many types of film have dominated motion picture production: e.g., nitrate (or nitro-cellulose, also called celluloid), cellulose acetate (aka "safety" film), and polyester film. While AV preservationist Dan Streible has argued for a strictly materialist and historically-rigorous use of the term 'film' that excludes borndigital movies and refers only to "strips of transparent material coated with light-sensitive emulsion" (Streible, 2013, p. 228), other AV archivists adopt a more expansive and flexible usage of the term 'film' to refer to "moving images in general as well as particular types of works, such as feature films, regardless of carrier" (Edmondson, 2016, p. 21).

My research focuses on film archives rather than $A V$ archives broadly conceived; that is, this essay centers on collections built primarily around photographic cinema originally created on film strips, with the understanding that film in a more capacious historical sense has been broadcast on television, watched on videotape, and circulated digitally. In practice, film archives are hybrid and convergent not only in terms of media format and carriers but also in an institutional sense, since particular film archives may have overlapping functions with other memory institutions-libraries, archives, and museumscollectively referred to as LAMs. My use of "film archive" also follows the lead of the names of the memory institutions I focus on-e.g., the NFAP and the Film Lab and film collections of the PIA-MPD.The prominence of the term film in such "organizational descriptors" (Edmondson, 2016, p. 21) indicates that, while the actual collections may encompass a diversity of audiovisual formats and carriers, film (in both narrowly materialist and expansively popular senses of the term) remains central to the mandate and priorities of these institutions.

5 Referred to only as the "Film Archive" or "Film Archives" in Marcos' Executive Order 640-A, the Film Archives' first Director-General, Ernie de Pedro, referred to the agency as the "Film Archives of the Philippines" with the acronym "NFAP" (despite the lack of "National" in its designation) in his 1986 report (de Pedro, 1986).

6 Since Pres. Duterte's appointment of Mary Liza B. Diño as the new Chair of the FDCP, the NFAP has not undertaken or continued any major restorations, despite the NFAP's acquisition of a state-of-theart 4K digital scanner under the prior FDCP Chair, Briccio Santos. Instead, the digitization of the pre-war film Zamboanga (Eduardo de Castro, 1936) was outsourced to Central Digital Lab, a privately-owned 
post-production company with strong ties to the media conglomerate ABS-CBN, in 2016 (Olgado 2016, 2017). Journalists and news columnists have been critical of the degree to which "arts and culture have taken a back seat to the war on drugs in the time of President Rodrigo Duterte" (Cabato, 2017).

7 Cinephile-collector and SOFIA member Teddy Co has aptly described the history of Philippine film archiving as a "Sisyphean history" of "fits and starts" (T. Co, 2012).

8 The PIA circulars that closed down the MPD and created the MISD in its stead were signed by PIA Director-General Renato S. Velasco. According to a Bloomberg Executive Profile, accessed online on March 2, 2017, Velasco is a political scientist at the University of the Philippines, Diliman with a B.A. degree in History, an M.A. in Asian Studies, and a Ph.D. in Political Science. In addition to serving as Trustee for the Local Water Utilities Administration (LWUA), he has been "chief of staff or consultant to various government offices" (Bloomberg, n.d.).

9 My research access requests for documents relating to the closure of the MPD and the creation of the MISD were approved by Herminio "Sonny" Coloma (2015, Coloma to F. Lim, October 14) , Secretary of the Presidential Communications Operations Office (PCOO) from 2010-2016). In the course of my research I encountered no archival policy documents relating to the decision to close down the MPD.

Edmondson underscores the "need for archival practice to be guided by an explicit policy so that decisions are policy-based rather than arbitrary." Archival management of audiovisual collections includes selection, acquisition, deselection, and disposal (defined as the "ethical divesting of carriers from a collection"). "Good policies are living documents" that are collaboratively authored and periodically revised to stay pertinent to on-the-ground realities; hopefully, collection management decisions guided by good policy documents avoid being "arbitrary, inconsistent, and unaccountable" (Edmondson, 2016, pp.63-64).

10 My research visits to the MISD Film Vault, which housed what remained of the former MPD's film collection, occurred during the PIA's turnover of the majority of their film holdings to the revived NFAP from 2013 to 2015.

11 The lifespan of photographic film — regardless of base polymer-is subject to deterioration that is spontaneous, inevitable, and irreversible. Cellulose acetate films are prone to vinegar syndrome, a form of decomposition whose onset is signaled by the odor of vinegar. Later, plasticizers that resemble crystals show up on the film's surface. Shrinking and warping of the film also occur. Polyester film, which began to be widely used from the mid-1990s until the transition to digital production, decomposes much more slowly than other film base polymers, though it is subject to problems like curling and delamination (NFSA, n.d.). Given that "heat and humidity are major contributors to the problem of vinegar syndrome" (Bigourdan, 2000, p. 4), the tropical Philippine climate likely hastened the demise of the defunct MPD's film collection in the absence of temperature and humidity controls.

12 Ray Edmondson is the Founding President of SEAPAVAA and former Deputy Director and now Curator Emeritus of the NFSA.

13 Created circa 1952, the NMPC predated the Marcos regime but was placed at the forefront of Marcos era media production after the 1972 declaration of Martial Law, when state media production was consolidated under its auspices (B. Capul, 2014; Official Gazette, n.d.). In 1986, Pres. Corazon Aquino founded the PIA through Executive Order 100. The PIA absorbed the functions, assets, and facilities of several Marcos-era entities, such as the assets of the Office of Media Affairs (OMA) and the NMPC, which 
were merged under NMPC director Gregorio Cendaña in 1980. The Aquino administration ordered the turnover of the OMA-NMPC's considerable assets to the PIA with the exception of Marcos-era radio and television units like the Bureau of Broadcast Services, Channel 4, and Channel 9 (the Maharlika Broadcasting System) (Aquino, 1986; Capul, 2014; Official Gazette, n.d.;Tuazon, 2015).

14 The entry on From a Season of Strife in the NFAP's "Film Inspection and Status Report" reads as follows: "heavy buckle and wave, faded color, scratches". (NFAP, 2017). With reference to Jean-Louis Bigourdan's four-part classification of the condition of cellulose acetate films, the print of Season of Strife is classified by NFAP archivists as actively decaying. An actively decaying film "may decay at a fast pace depending on storage conditions" but "can last a century in cold storage" (Bigourdan, 2000, pp. 1-2; NFAP, 2017).

15 According to a brief history of the MTRCB film collection prepared in 1999 and filed the PIA-MISD, "it was only in 1988 when MTRCB took the Archives under its fold." What remained of the nomadic NFAP collection was stored at the Manila Film Center until 1992 (seven years after the MTRCB's creation), when these remaining films were transferred to the offices of the MTRCB in Quezon City (PIAMISD, 1999).

16 The Memorandum of Agreement (MOA) between the MTRCB and the PIA notes that although the MTRCB was tasked with film preservation under EO 1051, its Film Archives and Library Division was incapable of maintaining a film collection due to its meager budget (i.e. financial constraints threatened the MTRCB films just as cost-cutting later imperiled the PIA Film Vault). The PIA, as a government agency that both preserved and restored films and maintained a film collection under the MPD, agreed to accept the films. Both the MTRCB and the PIA agreed to "protect ownership, copyright, storage/preservation, [and] access" to the films and to collaborate on the joint maintenance and preservation of these materials (MTRCB-PIA, 1999a). The joint agreement left the duration of the MOA unspecified.

17 According to the NFAP Annual Report, 2011-2012, MTRCB holdings in MOWELFUND's care were acquired by the NFAP in May 2012. „Acquired from Mowelfund Audiovisual Archives, the MTRCB Collection consists of $35 \mathrm{~mm}$ prints of full length features, trailers, trims and cuts. Notable titles in the collection are Minsa'y Isang Gamu-gamo by Lupita Kashiwara, Sakada by Behn Cervantes, and Olongapo: The Great American Dream by Chito Roño" (NFAP, 2013a, pp.5, 11). An NFAP Inventory of the MOWELFUND collection lists the elements for 713 film titles in a variety of gauges $(8 \mathrm{~mm}$, Super $8 \mathrm{~mm}, 16 \mathrm{~mm}, 35 \mathrm{~mm}$, and quarter inch/open reel) (NFAP, as of 2018).

18 Established in 1938, LVN Pictures was among the Big Three studios that dominated Philippine film production from the 1950s through the early 1960s. LVN is an acronym for the surnames of its three founders: Narcisa Buencamino Vda. de Leon, Carmen Villongco, and Eleuterio Navoa. According to film historian Nick Deocampo, "its color laboratory was known as one of the finest in Asia" (Deocampo, 2007, p. 256).

19 As discussed above (cf. note 7), audiovisual collection management-which includes deselection and disposal—should be carefully guided by documented archival policies (Edmondson, 2016, pp.63-64).The closure of the PIA-MPD, apparently implemented in the absence of the latter, created conditions under which archivists were subsequently left little choice but to dispose of the deteriorated remains of the LVN collection at PIA. What should have been a policy-driven process of deselection and disposal was short-circuited by the oxymoronic realities of "archival decay": that is, rather than preserving film elements against the ravages of time, archival conditions at the PIA after 2004 hastened 
the deterioration of titles entrusted to its custodianship.

20 Edmondson's Ph.D. thesis recounts the NFSA's history from 1935-2008, analyzing the institution's struggle to define its identity, assure "good governance", and achieve institutional autonomy from various umbrella organizations (first, the National Library of Australia, from which it separated in 1984, and later the Australian Film Commission, with which it first merged in 2003 and from which subsequently separated upon achieving "statutory status" and the passage of the NFSA Act in 2008. Edmondson traces a controversial and at times bitter history in which "questions about personal and institutional ethics, public officials' duty of care, managerial and financial competence, and the role of public activism, emerge repeatedly" (Edmondson, 2011, pp. vi-vii, 3).

21 In the library sciences, "gray literature" or gray papers - which include government documents and reports-are often ephemeral genres of internal institutional circulation, as opposed to formal, established routes of publication that reach a wide, general audience (Gitelman, 2014, 115-116). PIA gray literature are an integral part of my source materials for this paper.

22 The uniquely valuable quality of personal papers accumulated by cultural workers and institutional insiders is glossed by Edmondson, who reflects on his use of personal papers as follows: "The additional evidential dimension was my large collection of personal papers which contain unique unpublished material, and which could not have been separately assembled by any other researcher. Like any such collection, the content is by definition both arbitrary and incomplete, even though it was deliberately compiled over time to provide as complete a historical record as possible" (Edmondson 2011, p. 377, my emphasis).

23 Mary Del Pilar is the Head of the Film Archives in the ABS-CBN Corporation. She currently serves as a Board Member of SOFIA. She was the former Head of the PIA-MPD Film Laboratory from 19912000. In addition to having served as Executive Council Member of the NCCA Committee on Cinema, she is also a SOFIA founding member and past president, as well as a former SEAPAVAA Executive Council Member and Chair of the SEAPAVAA Technical Committee.

24 Victoria "Vicky" Belarmino is the current President of SOFIA and a cultural officer and film archivist of the CCP's Film, Broadcast, and New Media Production and Exhibition Department. She serves as Festival Coordinator for Cinemalaya, the Philippine film festival that helped spark a renaissance of the domestic film industry by fostering talented indie digital filmmakers. She was an Executive Council Member of the NCCA Committee on Cinema (2004-2010) and also served as an officer and Executive Council Member of SEAPAVAA (2008-2013). Early in her career, Belarmino was mentored by two premier historians of Philippine film: scholars Agustin "Hammi" Sotto (at SOFIA) and Nicanor Tiongson (at CCP), exemplifying the strong links between academia and archiving in the careers of SOFIA prime movers.

25 One of SOFIA's eight founding members, Belina "Bel" Capul's career bridges the Marcos and post-Marcos eras of film archiving, given her work at the Communications Research Office of the NMPC from 1979-1985 and her years at the PIA-MPD from 1986-2004, a period that coincides with the heyday of PIA's film restoration and preservation efforts. In the 1990s, as Head of the PIA-MPD, Capul trained film laboratory technicians in restoration processes, thus paving the way for the establishment of SOFIA. As SOFIA member and Past President (1996-1998), Capul supervised several film restorations and spearheaded the restoration of Tunay $\mathrm{Na}$ Ina, one of the earliest surviving Filipino films. She went on to serve as President of SEAPAVAA (2002-2008) and has served as the Chair of UNESCO's Memory of the 
World Marketing Subcommittee since 2009. She retired from the PIA in 2017.

26 Ma.Victoria"Vicky" Bejerano is a key PIA staff member whose career spans the transition from the defunct MPD to the current MISD; like Capul, Bejerano embodies much of these units' institutional memory. From 1991-2003, Bejerano worked as a Chemist and Sensitometrist at the MPD's Film Lab. From 2009 onwards, she has been the sole employee of the PIA Archives Unit under the MISD.

27 See Fossati, 2009. The founding of a graduate Moving Image Archiving and Preservation (MIAP) program at New York University in 2004 was key to this shift.

28 Cost-cutting at state entities during Gloria Macapagal Arroyo's presidency (2001-2010) belies the multiple corruption and plunder allegations that implicated her administration in various scandals, to wit:electoral fraud in the 2004 presidential elections; payoffs from jueteng gambling syndicates; kickbacks from telecommunications deals (NBN-ZTE); and fiscal malfeasance at the Philippine Amusement and Gaming Corporation (PAGCOR) and the Philippine Charity Sweepstakes Office (PCSO). Arrested on corruption charges in 2012 under the presidential administration of Noynoy Aquino, she was cleared of charges under the Supreme Court during the Duterte presidency (Mangahas, 2009; Whaley, 2012; Whaley, 2016).

29 The MISD is charged with several responsibilities, quoted as follows:

- $\quad$ Automated collection, organization, storage and retrieval of management oriented data/information,

- On-line retrieval and selective dissemination of data information for institutional decision making, and

- Operation of the PIA Library and integration of all PIA document collections in print, film, video, photo and slides. (Velasco, 2004d)

30 Quoted below are the figures cited by Tinig under the subheading, "Income Indicators":

In the three-year time frame used by the [MPD Review] Committee, it was found that the film laboratory had a decreasing annual income in transactions with the private sector. MPD earned P729,522 in 2001, P727,836 in 2002 and P357,431 in 2003.

...It is interesting to note that there is actually an increase in the annual interagency trust receipts in the three-year time frame used by the Committee. The annual average inter-agency trust receipt of $\mathrm{P} 3,857,2150$ is broken down into the following: $\mathrm{P} 623,821$ in 2001, $\mathrm{P} 1,877,952$ in 2002 and a high of $\mathrm{P9}, 069,873$ in 2003." (Leguiab, 11-12)

31 All English translations are my own; the oral history interview with Bel Capul was conducted in a mixture of Tagalog-based Filipino and English, or Taglish. Capul's syntax was characteristically elliptical, but "they" here appears to be referencing officials at the highest management level of the PIA.

32 PIA Special Order 195, which re-assigns personnel of the defunct MPD to other divisions, reads:"It is understood that all positions to be vacated by compulsory retirees under [the] Motion Picture Division will be reclassified/collapsed in order to create new positions for the Management Information System Division" (Velasco, 2004e, p. 2).

33 In order to screen Martial Law films in the PIA collection for my research on the archival preservation and restoration of Philippine cinema, I and SOFIA members (Belarmino of the CCP, Capul and Bejerano of the PIA) arranged an inter-agency collaborative film screening at PIA-MISD on 
September 8, 2014. The film inspection and technical equipment check were conducted by Belarmino, Alfred Nemenzo of the CCP, and Leonil Getes of the Philippine Administrative Network Project (PANP). Nemenzo projected the films, which ranged from titles in good or fair condition to actively decaying condition.

34 The high costs of film preservation and digital asset management mean that most moving image archives around the world constantly struggle to secure resources to assure their continued survival.For the first major restoration project undertaken by the NFAP in 2012, the Philippine government shouldered half of the cost of the restoration of a 1950 classic, Genghis Khan, which cost approximately 2 million pesos (San Diego, 2012) This might explain why the MPD, which carried out expensive film restoration projects, was singled out for cost-cutting. It also underscores the need for legislated funding for state film archives.

35 According to the NFAP, between August 22, 2013 and May 15, 2016, the total number of film elements turned over by the PIA to the NFAP are as follows: 4,341 identified films on celluloid; 93 unidentified films. The total number of cans containing the films on celluloid and sound on magnetic tape turned over was 7,247 (Patino, 2017). In 2017, the PIA donated additional audiovisual materials and motion picture equipment to the NFAP-FDCP as follows:"130 units (843 pieces) of functional and nonfunctional motion picture processing equipment and supplies, 33 titles of videotapes, and 10 titles (292 rolls) of films formerly held by the defunct Motion Picture Division" (Gaje, 2017).

36 "He said, and he was very very clear, since I was fighting for [film] preservation [under the MPD], well, if the government itself doesn't care, why do you push for it? I answered, who is the government? It's people like you who are on top and who can do something."

37 "In that sense I agree with you that the government has been remiss in terms of appreciating that [the importance of film preservation]... market forces are market forces, they are business-minded. But the government needs to see [the public interest in film preservation] and intervene. That seems to be what is lacking, lacking or absent. Especially since the leaders at government organizations are always changing, as though they're just passing through."

38 In the aftermath of Marcos' ouster, Deputy Minister of Culture Victor Ordoñez, in a background paper on the Presidential Commission on Culture and the Arts (PCCA) entitled "The Neglect of the Past", noted that the organizational structure of government cultural entities resulted in "cultural endeavors becoming private enclaves of certain influential people" (as cited in Fernandez, 1989, p. 495). Ignoring such critiques, all successive presidential administrations in the post-Marcos period have continued the fraught practice of presidential appointments for film-related state agencies. Today, the re-established NFAP inherits the organizational structure of its predecessor, since its current administrative chain puts it directly under the Office of the President via the FDCP.The organizational structure of the PIA is likewise subsumed under the Office of the President via the PCOO.

39 In the absence of relevant legislation, presidential appointees to head film-related state agencies with an AV archival function in the Philippines (such as the FDCP and PIA) have not come from a professional AV archival or curatorial background. In contrast, by law (i.e., the Philippine Libriarianship Act of 2003) only licensed librarians can be employed in Philippine government libraries. Duterte's appointment of a non-librarian, Cesar Gilbert Adriano, to the post of Director for the National Library of the Philippines led outraged librarians to charge that Duterte's appointment disregarded the Anti 
Graft and Corrupt Practices Act by "knowingly approving a benefit in favor of an unqualified individual" (Evangelista, 2018).

40 Plantilla refers to a permanent position of employment (specified by title and salary grade) in any government agency, office, or institution with a corresponding appropriation from the Department of Budget and Management.

\section{Acknowledgement}

I gratefully acknowledge the support of the Philippine Information Agency, the University of the Philippines, College of Mass Communication, and a Fulbright Scholar Grant in the completion of this research. I benefited immensely from the invaluable feedback of Carol Hau, Bono Olgado, Patrick Campos, Joya Escobar, Lucas Hilderbrand, Bel Capul, Vicky Bejerano, and the journal's anonymous readers.

BLISS CUA LIM is Associate Professor of Film and Media Studies at the University of California, Irvine. She is the author of Translating Time: Cinema, the Fantastic and Temporal Critique (Duke University Press, 2009; Ateneo de Manila University Press, 2011). She is a member of the Editorial Collective of the journal Camera Obscura: Feminism, Culture, and Media Studies, published by Duke University Press and serves on the Advisory Board of Plaridel: A Philippine Journal of Communication, Media and Society published by the University of the Philippines College of Mass Communication. (Author correspondence:flim@uci.edu) 